\title{
Antimicrobial Peptides Targeting Gram-Positive Bacteria
}

\author{
Nermina Malanovic ${ }^{1, *}$ and Karl Lohner ${ }^{1,2}$ \\ 1 Institute of Molecular Biosciences, Biophysics Division, University of Graz, NAWI Graz, \\ Humboldtstrasse 50/III, 8010 Graz, Austria \\ 2 BioTechMed Graz, Humboldtstrasse 50/III, 8010 Graz, Austria \\ * Correspondence: nermina.malanovic@uni-graz.at; Tel.: +43-316-380-4981
}

Academic Editor: Guangshun Wang

Received: 22 July 2016; Accepted: 13 September 2016; Published: 20 September 2016

\begin{abstract}
Antimicrobial peptides (AMPs) have remarkably different structures as well as biological activity profiles, whereupon most of these peptides are supposed to kill bacteria via membrane damage. In order to understand their molecular mechanism and target cell specificity for Gram-positive bacteria, it is essential to consider the architecture of their cell envelopes. Before AMPs can interact with the cytoplasmic membrane of Gram-positive bacteria, they have to traverse the cell wall composed of wall- and lipoteichoic acids and peptidoglycan. While interaction of AMPs with peptidoglycan might rather facilitate penetration, interaction with anionic teichoic acids may act as either a trap for AMPs or a ladder for a route to the cytoplasmic membrane. Interaction with the cytoplasmic membrane frequently leads to lipid segregation affecting membrane domain organization, which affects membrane permeability, inhibits cell division processes or leads to delocalization of essential peripheral membrane proteins. Further, precursors of cell wall components, especially the highly conserved lipid II, are directly targeted by AMPs. Thereby, the peptides do not inhibit peptidoglycan synthesis via binding to proteins like common antibiotics, but form a complex with the precursor molecule, which in addition can promote pore formation and membrane disruption. Thus, the multifaceted mode of actions will make AMPs superior to antibiotics that act only on one specific target.
\end{abstract}

Keywords: cell wall; lipoteichoic acid; peptidoglycan biosynthesis; membrane phospholipids; mode of action of AMPs

\section{Introduction}

For many years, the World Health Organization has emphasized the high proportions of antibiotic resistance in bacteria causing common infections such as pneumonia, urinary tract and blood stream infections in all regions of the world. Furthermore, their global report on surveillance in 2014 referred to alarming levels in bacterial resistance in many parts of the world and the urgent need to develop a global intervention plan against antimicrobial resistance [1]. One of the problematic microbes that causes a high percentage of hospital-acquired infections is the Gram-positive strain Staphylococcus aureus, which is resistant to a number of antibiotics, in particular methicillin. Although in general less Gram-positive bacteria are pathogenic to humans, some like Streptoccocus and Staphylococcus, which normally reside on healthy skin or in the nasopharyngeal region, can become pathogenic at certain conditions initiating skin infections, followed by sepsis, pneumonia, meningitis and in the worst case death [2]. The same is true for gut residing Enterococcus and Clostridia species. The former are associated with urinal infection in patients with catheter or catheter-related bloodstream infections and the latter is causing severe diarrhea by prolonged treatment with antibiotics or proton pump inhibitors $[3,4]$. In fact, a study involving 19 US hospitals during 2007 and 2010 revealed that the percentage of isolates of E. faecium being resistant to vancomycin was highest ( $87.1 \%$ ) followed by S. aureus resistance to 
oxacillin-methicillin (56.8\%) [5]. Pathogenicity of the foodborne Listeria monocytogenes is described to cause listeriosis, which mainly affects high-risk individuals such as pregnant women affected by the case of invasive infection [6]. Moreover, cases of pathogenic relevance of Lactobacillus strains, which are considered to be harmless, are also known [7]. Finally, tuberculosis is caused by the Gram-variable acid-fast Mycobacterium tuberculosis, which not only infects the lung, but also many other organs and tissues. Although treatment with conventional antibiotics is successful, tuberculosis is still one of the bacterial infections with the worldwide highest disease burden killing 1.5 million people per year [8,9]. The potential of antimicrobial peptides (AMPs) as novel therapeutic strategies in the treatment of tuberculosis was discussed in a recent review [10]. To conclude, in general, any bacterial strain may become pathogenic.

Thus, with the threat of a post-antibiotic era, research on host defense (antimicrobial) peptides [11-15] has markedly increased, as reflected by the more than 2600 natural or synthetic peptides with antimicrobial activity listed in the Antimicrobial Peptide Database (APD2, http://aps.unmc.edu/AP) [16]. Within the last decades, the number of new antibiotics steadily decreased and only recently two novel antibiotics, the antimicrobial lipopeptides daptomycin and oritavancin, were approved by the FDA for the treatment of severe infections caused by Gram-positive bacteria. The efficacy of daptomycin, produced by the soil bacterium Streptomyces roseosporus, against methicillin-resistant $S$. aureus was recently summarized [17]. Albeit oritavancin, a semisynthetic lipoglycopeptide, was only approved by FDA for the treatment of acute bacterial skin and skin structure infections, it is also a potential candidate where new innovative therapy is needed such as infective endocarditis and osteomyelitis [18]. The advantage in developing AMPs as therapeutic agents is that as such peptides are an intrinsic part of most living organisms [19-21], providing a first line of defense against a substantial array of pathogenic microorganisms, by direct killing as well as modulation of the immune response [22-25]. Owing to the fact that these molecules exhibit multifaceted mechanisms of action and frequently kill bacteria within minutes, development of resistance is less likely [12,26].

A large number of AMPs are considered to kill bacteria via a membrane damaging mechanism, although intracellular targets have been also reported. In any case, independent of their mode of action, AMPs encounter several potential interaction sites on their path to their target site. Adsorption of AMPs on the bacterial surface will be mainly driven electrostatically between the cationic peptides and negatively charged cell wall components such as wall- and lipoteichoic acids of Gram-positive or lipopolysaccharides of Gram-negative bacteria. Recent studies suggested that interaction of AMPs with bacterial cell wall constituents, including peptidoglycan, may reduce the local concentrations of AMPs at the cytoplasmic membrane and in turn their efficacy [27]. In fact, enormously high peptide coverage was needed to eradicate bacteria via a membrane damaging mode as shown for E. coli killing by PAMP-23, a cationic amphipathic helical peptide from the cathelicidin family [28].

Clearly, lipids are involved in all these steps and their molecular properties will have a strong impact on the consequent processes [29,30]. Therefore, it is also important to consider membrane architecture and lipid composition in order to understand the molecular mechanism and target cell specificity of AMPs as well as to design proper model systems. So far, it is well accepted that the different physicochemical properties of the (phospho)lipids found in biological membranes allow AMPs to discriminate between bacterial and host cell membranes [11,15,31,32]. Cholesterol, a major component of eukaryotic but not of bacterial cell membranes, seems to also play an important role in this process. The presence of this neutral lipid in model membranes inhibited the fragmentation of lipid vesicles by cationic, linear magainin derived AMPs [33,34]. In addition, high resolution structural studies provided structures on AMPs bound to lipid micelles as reported for human cathelicidin LL-37 [35,36] or magainin peptides $[37,38]$ to name a few. Structural NMR studies also provided experimental evidence for the mechanism of membrane disruption of these peptides [39-43]. In this review, the focus is on AMPs specifically acting against Gram-positive bacteria and hence emphasis is not only on the interaction of AMPs with the cytoplasmic membrane, but also with the cell wall components peptidoglycan and teichoic acids, as well as interference of AMPs with their biosynthesis. 
Moreover, as numerous reviews exist on membrane damaging activities of AMPs (e.g., [44] and references therein), we will not discuss in depth those mechanistic backgrounds but rather delineate mode of actions that may be relevant for Gram-positive bacteria with an emphasis on the diverse nature of bacterial cell envelopes of Gram-positive and Gram-negative bacteria.

\section{Structural Characteristics of AMPs}

The main characteristics of AMPs for high binding and selectivity toward microbial membranes have been extensively reviewed [45]. It was suggested that the amino acid composition determining the physicochemical properties of the peptide in respect to charge, amphipathicity, hydrophobicity, flexibility and H-bonding capacity are key factors for their mode of action and selectivity toward microbial cells [46]. Upon contact with microbial membranes, AMPs often undergo structural changes adopting defined secondary structures or oligomerize into aggregates that also account for the considerable diversity of antimicrobial mode of action [45]. At the end, amphipathicity, resulting from segregation of apolar and polar residues upon secondary structure formation favors internalization of the peptide and in turn membrane perturbation. Thereby, the presence of hydrophobic amino acids promotes stronger partitioning into membranes. Nevertheless, there is consensus that the positive charge of the peptide is essential for initial binding to the negatively charged bacterial membrane surface, which allows discrimination between bacterial and host cell membrane, and hydrophobicity is needed for insertion into and perturbation of the membrane [30,47].

However, what are the parameters that permit discrimination between Gram-negative and Gram-positive bacteria? Searching the antimicrobial peptide database [16], no obvious preference for targeting only Gram-positive or Gram-negative bacteria in respect of hydrophobicity, length and charge of amino acid residues as well as secondary structure of AMPs could be identified. Conjointly, the vast majority of these peptides are composed of 10-50 amino acids and exhibit a positive net charge (Table 1). Approximately 13\% of the entries account for larger peptides/proteins between 50 and 150 amino acid residues. For more than $60 \%$ of AMPs, the structure is not known. Further, the fraction of hydrophobic residues is mostly between $30 \%$ and $50 \%$, although it seems that Gram-positive bacteria have a somewhat wider distribution toward higher content of hydrophobic residues. However, one has to consider that the number of AMPs being specific for Gram-positive bacteria is much larger than for Gram-negative bacteria. In addition, this summary contains peptides from various sources. Therefore, we compared the fraction of hydrophobic residues of AMPs from diverse genera of frog, which had the largest entries in the Antimicrobial Peptide Database [16]. Displaying these data supports the above assumption (Figure 1). In this context, it is of interest that it has been suggested that high hydrophobicity may prevent peptide translocation through the outer membrane of Gram-negative bacteria [48].

Table 1. Characteristic physicochemical parameters of AMPs.

\begin{tabular}{cccc}
\hline & \multicolumn{3}{c}{ Antimicrobial Activity } \\
\cline { 2 - 4 } & Anti Gram-Positive & Anti Gram-Negative & Broad Spectrum \\
\hline peptide length & & 5 & 63 \\
10-50 AA & 16 & 153 & 1890 \\
50-100 AA & 361 & 37 & 211 \\
100-150 AA & 49 & 10 & 35 \\
net charge & 6 & & 11 \\
$>20$ & 0 & 4 & 57 \\
$11-20$ & 3 & 28 & 415 \\
$6-10$ & 51 & 145 & 1212 \\
$1-5$ & 308 & 14 & 112 \\
0 & 44 & 17 & 100 \\
\hline 0 & 26 & & \\
\hline
\end{tabular}


Table 1. Cont.

\begin{tabular}{cccc}
\hline & \multicolumn{3}{c}{ Antimicrobial Activity } \\
\cline { 2 - 4 } & Anti Gram-Positive & Anti Gram-Negative & Broad Spectrum \\
\hline \% hydrophobic residues & & & \\
$11-20$ & 1 & 6 & 57 \\
$21-30$ & 3 & 26 & 155 \\
$31-40$ & 27 & 41 & 544 \\
$41-50$ & 136 & 73 & 704 \\
$51-60$ & 103 & 26 & 440 \\
$61-70$ & 76 & 10 & 264 \\
$71-80$ & 76 & 1 & 20 \\
$81-90$ & 3 & 1 & 3 \\
$>90$ & 1 & 0 & 3 \\
\hline secondary structure & 1 & & 1385 \\
unknown & & 127 & 348 \\
helix & 305 & 19 & 77 \\
beta-strand & 38 & 7 & 3 \\
helix \& beta strand (unpacked) & 8 & 0 & 59 \\
helix \& beta strand (packed) & 4 & 3 & 236 \\
disulfide bonds & 16 & 23 & 70 \\
rich in unusual AA & 52 & 23 & 2199 \\
Total AMP entries ${ }^{1}$ & 0 & 205 & \\
\hline
\end{tabular}

${ }^{1}$ number of AMPs found in the Antimicrobial Peptide Database in each linkage [16].
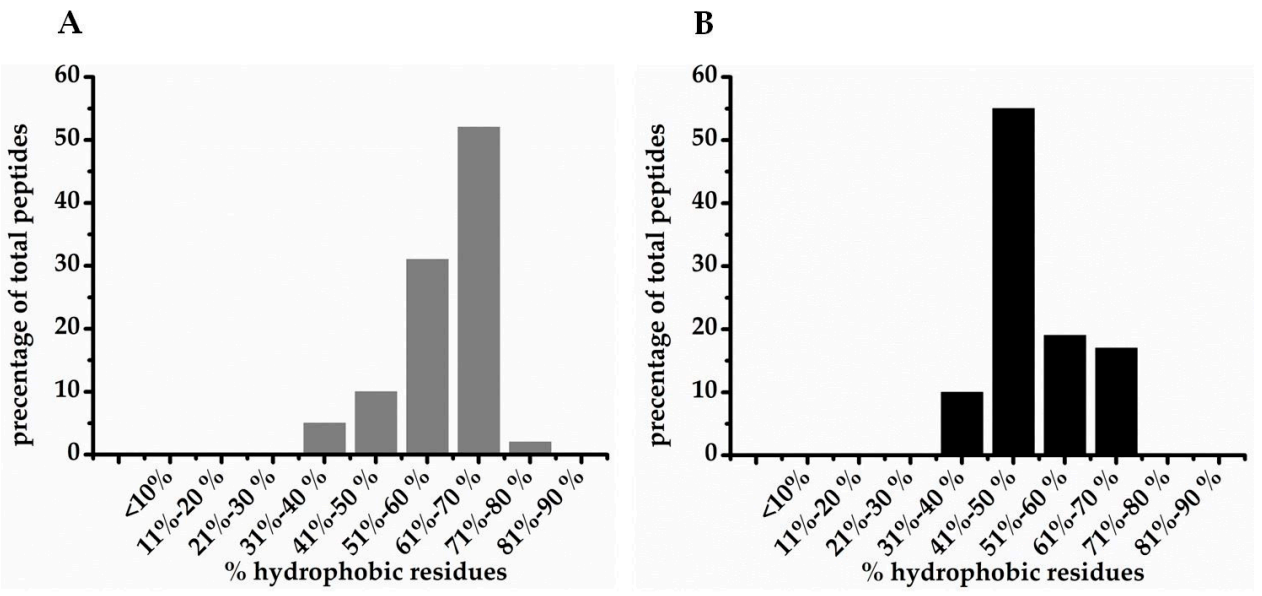

Figure 1. Percentage of hydrophobic residues of frog antimicrobial peptides (AMPs) in relation to the number of total peptides acting only against Gram-positive (A) and Gram-negative; (B) bacteria, respectively. The Antimicrobial Peptide Database [16] displays 401 peptides from diverse genera of frog active against both, Gram-positive and Gram-negative bacteria. Sixty one AMPs are found to be specific for Gram-positive and 42 for Gram-negative bacteria, whereby only peptides are considered with MIC < $100 \mu \mathrm{M}$ or $100 \mu \mathrm{g} / \mathrm{mL}$.

\section{Architecture of Gram-Positive Cell Envelopes}

Beyond the classification of bacteria according to Gram staining of peptidoglycan (PGN), bacteria can be subdivided by the cell shape into bacilli (rod-shaped) and cocci (sphere-shaped). Typical representatives of Gram-positive coccis form clusters (Staphylococcus), chains (Streptococcus) or tetrades (Micrococcus), whereas the Gram-positive bacilli can be thin, thick or branched. Bacteria with typical cocci form are rich in phosphatidylglycerol, whereas bacilli have in addition significant 
amounts of phosphatidylethanolamine (Table 2). A number of bacteria like actinomycetes and cell-wall deficient bacteria including mycoplasma and L-form bacteria show different morphologies that largely result from their differences in cell wall and plasma membrane lipid composition (Figure 2, Table 2). The molecular shape of actinomycetes looks to be somewhere in between rods and coccis organized in a branched network of hyphae, while mycoplasma and L-form bacteria can be round to oblong. The cells of cell-wall deficient bacteria are often observed as pleomorph and polymorph, but their colonies rather show egg-fried structures. Also, guanine and cytosine content of their genomes as well as their respiration type are often taken into consideration to differentiate between bacterial species or to explain their pathogenicity $[49,50]$. However, common to all bacteria is that the cytoplasmic membrane is surrounded by a cell wall. Those two compartments are separated by a periplasmic space or periplasm, which contains a wide variety of ions and proteins essential for numerous functions involving (electron) transport, substrate hydrolysis, degradation and detoxification. The cell wall of Gram-positive bacteria is made of many PGN layers of about 40-80 nm that stabilize the cell membrane [51]. In addition, the cell wall of Gram-positive bacteria contains a further unique component, teichoic acid that can be anchored to a glycolipid anchor with the plasma membrane or linked to the $N$-acetyl muramic acid unit of PGN. A cell wall does not exist in mycoplasma, L-form bacteria and some archaebacteria [52]. The plasma membrane is a phospholipid bilayer consisting of an inner and an outer leaflet (Figure 2), whereby the nature of phospholipids varies amongst the species not only in terms of their headgroups but also of their fatty acid moieties (Table 2). Basically, in comparison to Gram-negative bacteria, Gram-positive bacteria have a larger fraction of negatively charged phosphatidylglycerol (PG) containing saturated and unsaturated fatty acid with major distribution of C16:0, C18:0, C16:1 and C18:1, but also branched fatty acids like anteiso C15:0 and $\mathrm{C} 17: 0$ chains. 
Table 2. Major lipid species detected in cytoplasmic membranes of representative Gram-positive bacteria.

\begin{tabular}{|c|c|c|c|c|c|c|c|c|c|c|}
\hline \multirow{2}{*}{ Organism } & \multirow{2}{*}{$\begin{array}{l}\text { Morphology } \\
\text { Cell/Colony }\end{array}$} & \multicolumn{7}{|c|}{ Weight Percentage of Total Lipid of Cell Membrane } & \multirow{2}{*}{ Major Fatty Acids } & \multirow{2}{*}{ References } \\
\hline & & PG & lysyl-PG & $\mathbf{P I}^{\mathbf{a}}$ & PE & $\mathrm{CL}$ & NL & Others $^{b}$ & & \\
\hline Cocci & round/chain & & & & & & & & & \\
\hline Staphylococcus aureus & round/cluster & 43 & 30 & - & - & 22 & - & 5 & $\begin{array}{l}\text { ai-C15:0; C18:0 } \\
\text { ai-C17:0; C20:0 }\end{array}$ & {$[53,54]$} \\
\hline Enterococcus faecium & round/diplococci & 33.8 & 14.4 & - & - & 39 & - & 12.8 & $\begin{array}{l}\text { C16:0; C16:1w7c } \\
\text { C18:1w7c }\end{array}$ & [55] \\
\hline Streptococcus sanguis & round/diplococci & 82 & - & - & - & 18 & - & - & $\mathrm{C} 18: 1 ; \mathrm{C} 16: 1 ; \mathrm{C} 16: 0$ & {$[56,57]$} \\
\hline Streptococcus pneumoniae & round/cocci lancet shape & 50 & - & - & - & 50 & - & - & C16:0; C16:1; C18:0 & [58] \\
\hline Actinomycetes & $\begin{array}{c}\text { spherical } \\
\text { pleomorph/filamentous }\end{array}$ & & & & & & & & & \\
\hline Corynebacterium glutamicum & rods/V-shaped & 72.4 & - & 13.1 & - & 14.1 & - & 0,4 & C16:0; C18:1 & {$[59,60]$} \\
\hline Streptomyces hygroscopicus & rods, mycelium & - & - & 7 & 36 & $16^{c}$ & 30 & 11 & i-C16:0; i-C14:0; i-C15:0 & [61] \\
\hline Mycobacterium tuberculosis & $\begin{array}{c}\text { long, slender } \\
\text { rods/filamentous }\end{array}$ & - & - & 13 & 5 & 6 & 54 & 22 & $\mathrm{C} 16: 1, \mathrm{C} 18: \mathrm{Me}$ & {$[62,63]$} \\
\hline Cell wall deficient & polymorph/fried egg & & & & & & & & & \\
\hline Mycoplasma hominis ${ }^{\mathrm{d}}$ & round to oblong/fried egg & 33 & - & - & - & - & 60 & 7 & C16:0; C18:0; C18:1 & [64] \\
\hline L-form S. aureus & polymorph/fried-egg & 26 & 17 & - & - & 54 & & 3 & $\begin{array}{l}\text { ai-C15:0; C18:0 } \\
\text { ai-C17:0; C20:0 }\end{array}$ & {$[53,65]$} \\
\hline L-form S. hygroscopicus & polymorph/fried-egg & - & - & 13 & 37 & 22 & 16 & 12 & $\begin{array}{l}\text { ai-C15:0; ai-C17:0, } \\
\text { i-C16:0; C18:2 e }\end{array}$ & [61] \\
\hline Bacilli & $\begin{array}{l}\text { round-ended cylinders/ } \\
\text { single or in chains }\end{array}$ & & & & & & & & & \\
\hline Clostridium difficile & $\begin{array}{l}\text { large, blunt-ended rods / } \\
\text { pairs or chains }\end{array}$ & 100 & - & - & - & - & - & - & $\begin{array}{l}\text { C16:0; C16:1 } \\
\text { C18:0; C18:1 }\end{array}$ & [66] \\
\hline Bacillus subtilis & Rods/chain & 70 & - & - & 12 & 4 & - & 14 & ai-C15:0; i-C17:0 & [67-69] \\
\hline Listeria monocytogenes & $\begin{array}{l}\text { slender, short rods/ } \\
\text { single or in chains }\end{array}$ & 29 & 23 & - & 9 & 22 & - & 17 & $\begin{array}{l}\text { ai-C15:0; i-C15:0; } \\
\text { i-C17:0 }\end{array}$ & [70] \\
\hline
\end{tabular}

a PI+PI mannosides; ${ }^{\mathrm{b}}$ "Others" corresponds mainly to glycolipids besides of traces of other lipids; ${ }^{\mathrm{c}} \mathrm{CL}+\mathrm{CL}$ derivatives; ${ }^{\mathrm{d}}$ sterol-requiring mycoplasma; ${ }^{\mathrm{e}}$ major fatty acids only in neutral lipids (NL); i, iso-branched; ai, anteiso branched fatty acids. 

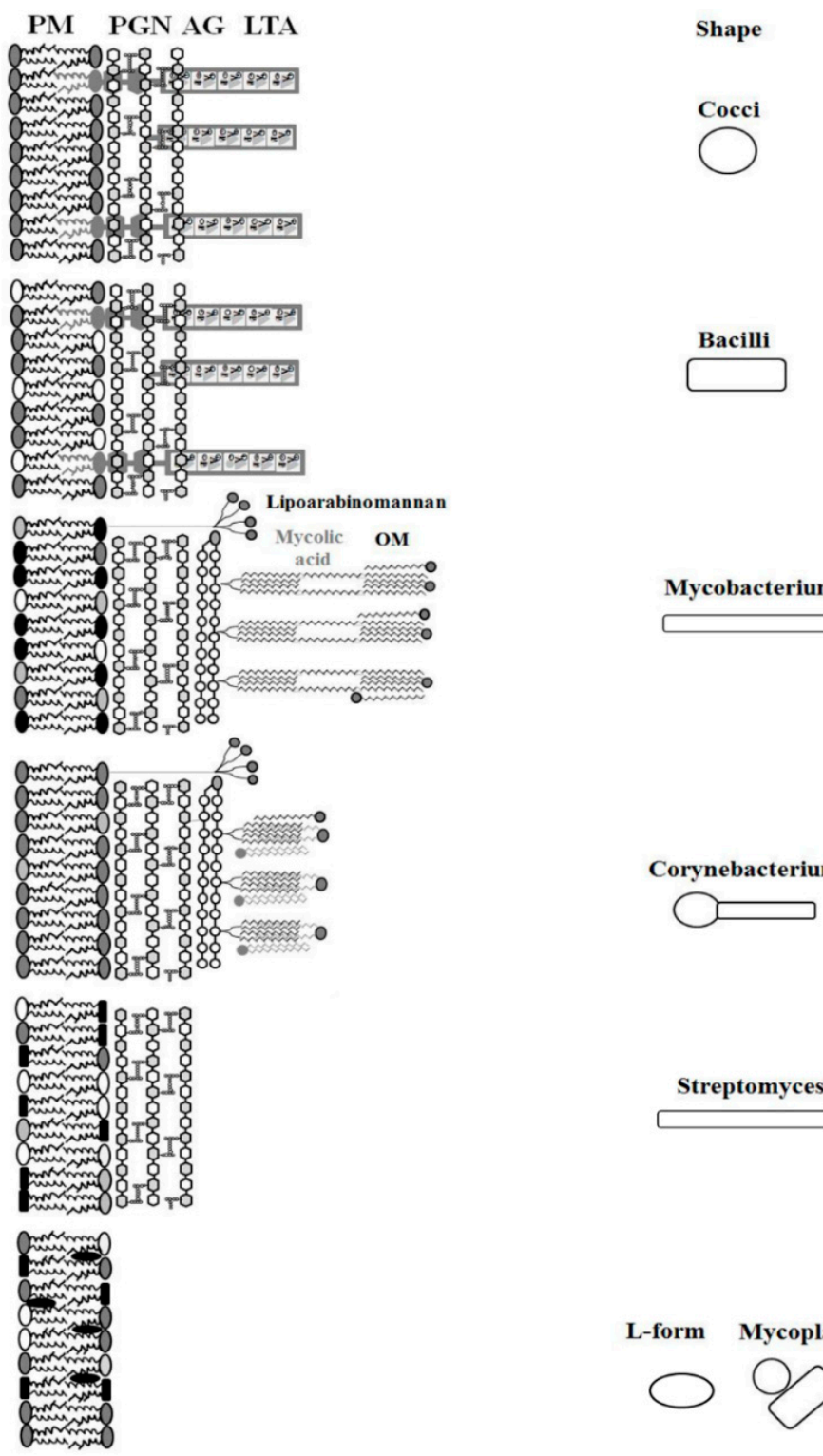

Figure 2. Schematic representation of membrane organization and morphology of selected Gram-positive bacteria. Gram-positive bacteria are characterized by a phospholipid bilayer of different composition (white ellipsoid, neutral phospholipid; grey ellipsoid, anionic phospholipid; black ellipsoid, cholesterol; black squares, neutral lipid). With the exception of L-form bacteria and mycoplasma, the plasma membrane (PM) of most Gram-positive bacteria is covered by peptidoglycan (PGN), which is a major component of the bacterial cell wall. The cell wall of cocci and bacilli contain also lipoteichoic acid (LTA), whereas mycobacteria and corynebacteria contain arabinogalactan (AG) and outer membrane (OM) composed of mycolic acid, sugar and lipids.

\subsection{Peptidoglycan, a Cell Wall Mesh}

Because of its rigidity, PGN determines the strength and characteristic cellular shape of bacteria, as shown e.g., for L-form bacteria from Bacillus subtilis [71] and in production of spheroplasts in E. coli [51,72]. PGN is a multi-gigadalton bag-like molecule and accounts for around $90 \%$ of the dry weight in Gram-positive and 10\% in Gram-negative bacteria. The molecular weight of single layered E. coli PGN sacculus is $3 \times 10^{9} \mathrm{Da}$, which is in the same range as a chromosome $\left(2.32 \times 10^{9} \mathrm{Da}\right)$ of this bacteria [51]. In Gram-positive bacteria, the PGN network makes up 40-80 layers and is composed of alternating units of disaccharide $\mathrm{N}$-acetyl glucosamine and $\mathrm{N}$-acetyl muramic acid 
(NAG-NAM) cross-linked by a pentapeptide side chain (stem) [51,72] (Figure 3). The pentapeptide usually has the sequence L-alanyl- $\gamma$-D-glutamyl-diaminopimelyl-L-lysyl-D-alanyl-D-alanine [51,72] In Gram-positive bacteria, an inter-bridge structure of five amino acid residues that varies between the species (e.g., five glycine molecules in Staphylococcus aureus) links two disaccharide-pentapeptide moieties [51,73]. PGN synthesis starts on the cytosolic side of the bacterial cell membrane from the common building block, lipid II (see e.g., [74]) that consists of a polyisoprenoid anchor of $\mathrm{C}_{55}$ carbons in a chain (11 subunits long, $\mathrm{C}_{55}-\mathrm{PP}$ ) attached to one disaccharide-pentapeptide subunit via a pyrophosphate linkage. The lipid II monomer is translocated to the periplasmic (exterior) side of the bacterial cell membrane before it is incorporated into the growing PGN network. Different findings and models for organization of the PGN murein sacculus have been proposed and it has been a matter of debate if murein glycans and peptides are arranged parallel (layered model) or perpendicular (scaffold model) to the membrane $[51,75,76]$. Recent NMR studies revealed that the disaccharide backbone of Gram-positive bacteria adopts four-fold screw helical symmetry with disaccharide unit periodicity of $4 \mathrm{~nm}$ [73]. Each PGN stem is oriented $90^{\circ}$ in respect to the previous stem and the lattice of crosslinked stems has parallel orientation.

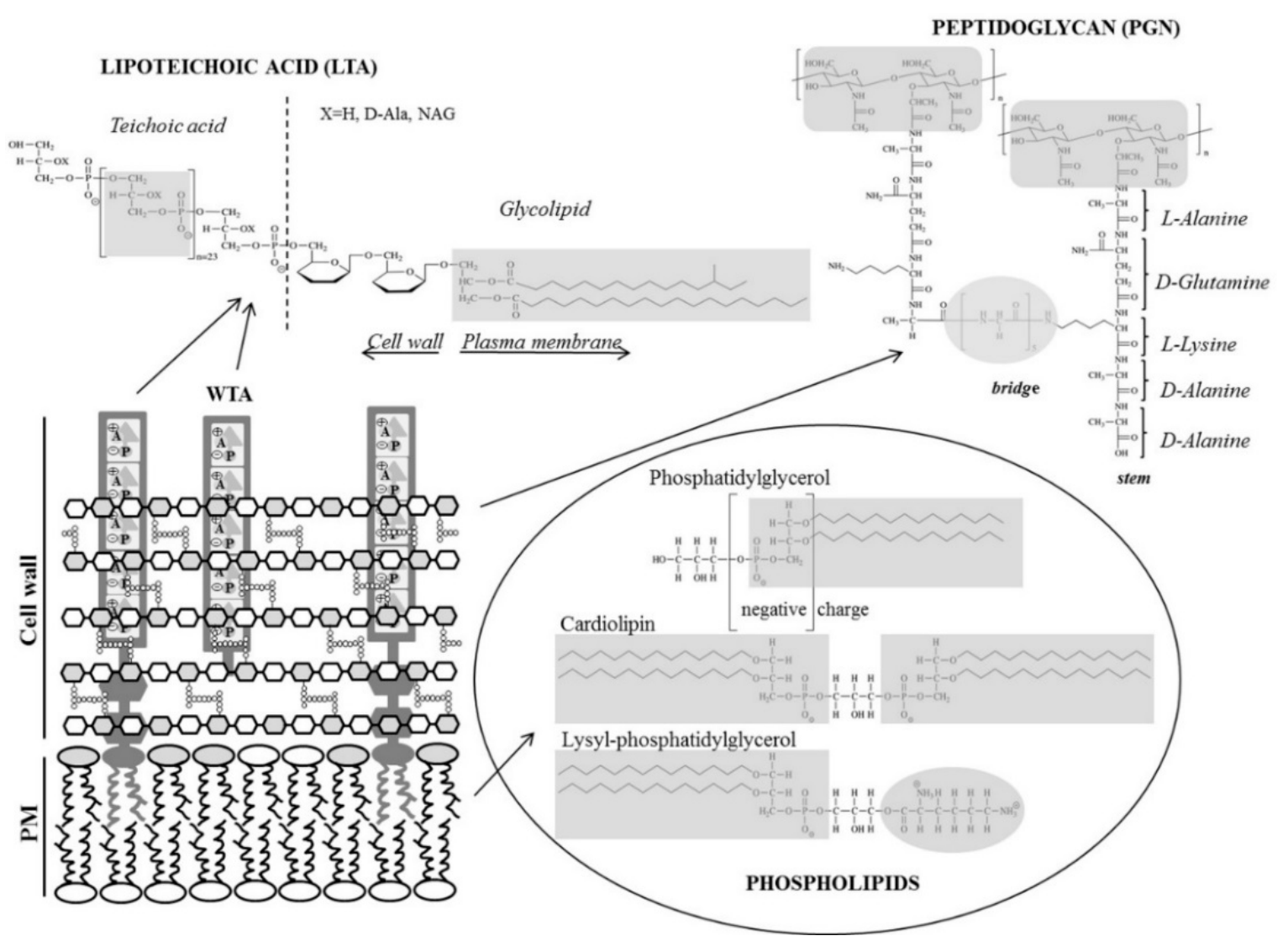

Figure 3. Schematic illustration of the cell envelope and main components of cell wall and plasma membrane (PM) of $S$. aureus, as a representative of Gram-positive bacteria.

\subsection{Lipoteichoic Acid, an Anionic Polymer Matrix}

Teichoic acids are important constituents of many Gram-positive bacteria, which are either tethered to the cytoplasmic membrane via a glycolipid (lipoteichoic acid, LTA) [77] or covalently anchored to the $N$-acetylmuramic acid of the peptidoglycan network (wall teichoic acid, WTA) [78] (Figure 3). Among other physiological functions, they play a role in determining the cell shape and in regulation of cell division [78,79]. For detailed information on LTAs, the reader is referred to a recent review by Reichmann and Gründling [80]. Wall teichoic acid polymers share a common linkage unit, 
but exhibit structural diversity in their repeat units. Four different classes of teichoic repeat units are described $[79,81]$. The basic structure of teichoic acid comprises a soluble polymer of glycerolphosphate or ribitolphosphate repeating units, which may vary from 15 to 50 residues between Gram-positive species. The glycolipid anchor in S. aureus is diglycosyl-1,2-diacylglycerol with two fatty acids of different composition [82], mostly C14:0 or branched C15:0 at the sn-2 position and C16:0, C18:0 or C20:0 at the sn-1 position of the glycerol moiety [83]. LTA deficient ltaS mutant of S. aureus exhibits aberrant cell growth and division. It is synthetic lethal with tagO mutant defective in WTA synthesis indicating that LTA and WTA compensate for their activities. Complete loss of the anionic polymer matrix in bacterial envelopes affects the growth leading to unviability of the cells [84].

In the outer membrane layer, the concentration of LTA ranges between $0.4 \%$ and $1.6 \%$ of the cell dry weight in the logarithmic growth phase [85], which means that the molecular ratio of phospholipid to LTA is around 10:1 [83,86]. In contrast to membrane lipids, LTA does not form a stable monolayer structure in aqueous dispersions [87], but a micellar supramolecular structure [88]. The structure of staphylococcal [88] and pneumococcal LTA micelles [89] was characterized by X-ray scattering revealing a total diameter of $22 \mathrm{~nm}$. The core, made of hydrocarbon chains of the glycolipid anchor, is $5 \mathrm{~nm}$, which is surrounded by an $8.5 \mathrm{~nm}$ shell of heavily hydrated hydrophilic chains. As observed for several bacterial species, the critical micelle concentration of LTA in phosphate-buffered saline ranges from 28 to $60 \mu \mathrm{g} / \mathrm{mL}$ [90]. Systematic thermodynamic studies on the miscibility of LTA with dipalmitoyl-phosphatidylglycerol (DPPG) revealed stable mixtures up to LTA concentrations of $20 \mathrm{~mol} \%$ [87]. Incorporation of LTA in the DPPG matrix led to an increase of the phase transition temperature indicating a stabilizing effect on lipid membranes within the head group region [83]. At concentrations higher than $20 \mathrm{~mol} \%$ phase separation occurs, accompanied by a destabilization of the lamellar aggregation of DPPG and segregation of LTA into the sub-phase, presumably in the form of micelles owing to the small cross-sectional parameter of the diacylglycerol moiety and the resulting conical shape of LTA [83].

\subsection{Plasma Membrane Phospholipids}

The main lipids found in Gram-positive membranes are summarized in Table 2. The phospholipid composition from one species to another may vary, but in general Gram-positive bacteria rather exhibit a high amount of phosphatidylglycerol (PG) and its derivates lysyl-phosphatidylglycerol (lysyl-PG) and cardiolipin (CL), respectively. To some extent, phosphatidylethanolamine (PE) is also present in Gram-positive cytoplasmic membranes. Moreover, phospholipids of Gram-positive species are characterized by a high content of branched-fatty acids, which were shown to influence the activity of AMPs [91]. The main physicochemical properties of these major bacterial phospholipids are summarized in Table 3. The major differences between PG and PE molecules, which are considerably important for the two-dimensional organization in membranes, relate to their net charge and their molecular shape. PGs are negatively charged at neutral $\mathrm{pH}$, while PEs are zwitterionic. PEs in turn have an inverted cone-like molecular shape owing to the smaller headgroup area as compared to the cross sectional area required by the acyl chains and therefore are prone to form non-planar lipid aggregates, such as the inverted hexagonal phase, imposing a curvature strain onto the membrane [92,93]. Anionic lipids like PG with its charged headgroup occupy a larger area than predicted by its geometrical size owing to electrostatic repulsion resulting in looser packing [94]. The molecular shape of PG can be described as a cylinder, i.e., the cross sectional area of the headgroup matches the hydrophobic cross sectional area $[95,96]$. Moreover, PE lipids interact inter-molecularly by hydrogen bonding between the amino- and phosphate groups or carbonyl group of the sn2-chain, which favors closer lipid packing $[97,98]$. Therefore, PE will tend to adopt structures with higher intrinsic curvature, while PG will rather form flat lamellar lipid aggregates. Indeed, non-ideal mixing behavior and packing constraints were detected in binary lipid mixtures of di-saturated and mixed-chain PG/PE [99,100]. Thus, the molar ratio of PG and PE is important in determining lateral organization, packing and/or mobility, which can be amplified by the interaction with other membrane constituents, in particular 
by membrane-active molecules. For example, studies on the interaction of AMPs with DPPG/DPPE showed that both the human neutrophil peptide, HNP-2, and PGLa, a peptide from the skin secretion of the African clawed frog Xenopus laevis, discriminate between the different phospholipid subspecies inducing lipid segregation [31].

Table 3. Typical physicochemical properties of Gram-positive bacterial phospholipids.

\begin{tabular}{ccccc}
\hline & PG & lysyl-PG & CL & PE \\
\hline Net charge & -1 & +1 & $-2(-1)^{*}$ & 0 \\
\hline H-bonding ability & no & no & yes & yes \\
\hline Molecular shape & cylindrical & truncated cone & inverted truncated cone & inverted truncated cone \\
\hline Intrinsic curvature & zero & positive & negative & negative \\
\hline Organization & bilayer & bilayer & inverse micelles & inverse micelles \\
\hline & & $*$ for details see text and [101].
\end{tabular}

The physicochemical properties and phase behavior of CL are summarized in detail by Lewis et al. [102]. In brief, the relatively small size of the polar headgroup should promote greater cohesion between the CL hydrocarbon chains, which in turn should elevate the lipid phase transition temperature relative to those of most other phospholipids. In agreement, CL was shown to pack tightly, forming micro domains [101]. Further, the small size of the polar headgroup should also enhance the propensity of CL to form inverted non-lamellar lipid phases, which is attenuated by the presence of the mutually repulsive negative charges of the phosphate groups but promoted in the presence of divalent cations [103]. Nevertheless, the presence of CL in a membrane may still be a driving force towards an increase in membrane curvature strain. Haines et al. [101] described the head group as a bicyclic formation of the two phosphate groups linked to the central glycerol residue. Thereby, the H-bonding to the hydroxyl residue alters the $\mathrm{pK}_{\mathrm{a} 2}$ to $>8$ and creates, by trapping a proton, an acid-anion. Therefore, at physiological conditions, $C L$ rather has a single negative net charge.

Numerous studies provide evidence that lipid composition determines the final morphology of every membrane and that the physicochemical properties of lipids, especially geometrical and physical constraints, contribute to a large extent to membrane organization. The first lipid domains were described for E. coli [104] and B. subtilis [105] found to be enriched in CL. They are located at the cell pole and septum. For these rod shaped bacteria, it was shown that the high cell-wall curvature at the poles and septum of bacteria is enriched in cardiolipin being essential for cell division [105-107]. Of note, as mentioned above, $\mathrm{CL}$ is a lipid prone to adopt non-bilayer structures of high curvature [103]. The shape of $E$. coli bacterium is suggested to be maintained by the separation of CL rich domains, as it is not well miscible with the major membrane constituent PE [108]. The same would be true for B. subtilis, which consists mainly of PG and lower amounts of PE and CL (Table 2). Notably, CL is also not very miscible with PG [109]. As well, PG was found to form distinct domains [110]. In B. subtilis it is distributed on helical structures along the cell surface, while in E. coli dot-like domains are observed. As illustrated recently, variability in the lipid composition of membrane domains may be a general factor shaping the interaction of membranes and proteins that is crucial for many different processes in bacteria including cell division [111,112].

Cell fractionation of $S$. aureus revealed that the cell wall makes up to $21 \%$ and membranes up to $10 \%$ of the cellular dry weight, whereby $90 \%$ of the lipids were found in the membrane and $10 \%$ in the cytoplasm [65]. In staphylococcal membranes, PG species make up to $95 \%$ of the total lipids [53]. No free fatty acids could be detected in S. aureus ([113]. Kuhn et al. [114] summarized a list of essential genes showing that mutations in $c d s A, p g s A$ and $p l s Y$ genes prevent synthesis of PG and its precursor acyl-glycerol-3-phosphate. Deletion of these genes is lethal. CL is the second most abundant lipid in Gram-positive bacteria, but generally it is present to a lesser extent in exponentially growing cells and rather accumulates in the stationary growing cells, where PG declines [115]. The same holds for 
lysyl-PG. Possible explanations to growth-related changes of phospholipid composition have been reported to include environmental conditions as well as regulation of cell cycle or DNA replication [114]. In addition, exposure to antibiotics that inhibit cell wall biosynthesis such as vancomycin, ampicillin or bacitracin stimulate the incorporation of lysine into PG [116], which seems to be also a protective mechanisms of Gram-positive bacteria against AMPs. This way, they reduce the overall negative charge on the surface by decorating the head group of PG with lysine, which with its two positive charges neutralizes the phosphate and confers a positive net charge to the modified lipid reducing the susceptibility to AMPs [117]. In fact, mprF mutants defective in synthesis of lysyl-PG showed increased susceptibility to a number of AMPs [114,118]. Information on chain packing and morphology of lysyl-DPPG was obtained in a differential scanning calorimetry and X-ray scattering study [119]. Under physiological conditions, the synthetic lysyl-DPPG resembled the parent lipid (DPPG) with respect to its melting behavior. However, in contrast to DPPG, lysyl-DPPG forms an interdigitated lamellar phase below the chain-melting transition owing to its large headgroup area, which will also affect the packing properties in bacterial plasma membranes.

It is interesting that actinomycetes e.g., corynebacteria, which usually have a shape between cocci and rods, the so-called coryneum, incorporate negatively charged phosphatidylinositol (PI) and its glycosylated derivatives in the membrane. This is needed to stabilize and strengthen their membranes, as they do not have glycosylated lipid anchors like LTA [120]. In addition to PGN, corynebacteria and mycobacteria have an outer membrane composed of trehalose derivatives, free lipid and mycolic acid, as well as a layer with arabino-galactan. All these components are missing in Streptomyces, another member of actinomycetes, which also display a strong variety of fatty acids. While in the cell wall of mycobacteria very long chain fatty acids $\mathrm{C}_{60-90}$ ( $\alpha$-alkyl, $\beta$-hydroxyl FA, mycolic acids) are found. In others, shorter carbon chains $\mathrm{C}_{22-36}$ consisting of a mixture of saturated and unsaturated FA occur [120]. The longer chain fatty acids are believed to play a role as a second permeability barrier functionally similar to the outer membrane of Gram-negative bacteria. Accordingly, mycobacteria contain both fatty acid synthase (FAS) I and II systems for de novo biosynthesis and elongation of fatty acids, whereas corynebacterium have only FAS I and Streptomyces has FAS II (for a review see [120]). Streptomyces and corynebacteria incorporate fatty acids not only in phospholipids but also in neutral lipids suggesting that the more cell wall components a bacterium loses, the more neutral lipids, e.g., triacylglycerol in Mycobacterium tuberculosis [62] or diacylglycerol in Streptomyces hygroscopicus [61], are found in their membranes. The same is true for mycoplasma, which are the smallest self-replicating prokaryotes having only a plasma membrane largely composed of PG or CL without cell wall or other lipid containing structures. However, they can uptake lipids from the environment or host and incorporate them in the membrane to stiffen them, e.g., by incorporation of sterol/sterol ester and triglycerides in Mycoplasma hominis [64] or PC and sphingomyelin in Mycoplasma hyopneumoniae, a pathogen isolated in China [121]. In accordance with this observation incorporation of cholesterol in cell wall-deficient Acholeplasma laidlawii abolished the gel-to-fluid phase transition [122,123]. Thus, maintaining membrane integrity makes the membrane of mycoplasma more similar to eukaryotic membranes and allows them to survive in a host. Normally, bacterial membranes do not contain sterol species.

Bacteria capable of mutating into a cell-wall-deficient "L-form" state proliferate by usual membrane deformation and scission process ranging from growth and shape distortion after losing the cell wall, to blubbing, tabulation and vesiculation [71]. Errington et al. [71,124] uncovered the crucial role of branched chain fatty acid synthesis in proliferation of the primitive cells of $B$. subtilis. Branched chain fatty acid deficient mutants went through pulsating shape changes, but failed to undergo membrane scission and separation of progeny, which was attributed to a reduction in membrane fluidity. To maintain an acceptable level of fluidity, bacteria alter their fatty acid composition by incorporation of lower melting fatty acids, such as unsaturated, short chain and branched chain fatty acids. In Gram-positive bacteria, modification of the ratio of saturated to unsaturated fatty acids and modification of the ratio of iso- and anteiso-fatty acids contributes to this adjustment. The importance 
of membrane composition for vesicle scission was demonstrated by optical microscopy experiments monitoring real-time incorporation of oleic acid into giant phospholipid vesicles explaining vesicle self-replication as a result of imbalance between membrane surface area and vesicle volume $[125,126]$. Thus, it was concluded that in order to proliferate, L-form bacteria compromise the loss of cell wall by intercalation of amphipathic molecules like fatty acids into the bilayer to increase the surface area above the internal volume of the cell that directly drives the shape distortion leading to vesicle fission.

\section{Mode of Action of AMPs}

The general view is that most AMPs act directly on cell membranes, but several in vivo studies have revealed that AMPs can interfere with a series of cellular processes and metabolic functions $[24,127,128]$. Intracellular targets such as nucleic acids and proteins have been proposed for those AMPs with very low membrane perturbing activity [129] via a "Trojan-horse" like mechanism for the peptide-uptake as shown e.g., for buforin II, which penetrates into E. coli cells and inhibits cellular function by binding to DNA and RNA [130] or cathelicidin-derived short Pro-rich peptides, which inhibit protein translation in 70S ribosomes or assembly of the large subunit of ribosomes [131]. A pioneering contribution to this aspect came from a study by Bob Hancock's group [132]. They tested peptides of different structures including $\alpha$-helical indolicidin variants differing in amphipathicity, charge, length and hydrophobicity, as well as a linearized bactenecin, Bac2A- $\mathrm{NH}_{2}$, against a panel of Gram-positive bacteria. All peptides exhibited membrane permeabilization, which however did not correlate with the antimicrobial activity of these peptides ranging from excellent to moderate. Although the exact mode of action of those peptides in Gram-positive bacteria has not been elucidated, based on the fact that at early time points membrane depolarization was not complete, even when more than $90 \%$ of bacteria had been killed, the authors concluded that cytoplasmic-membrane depolarization may not be the primary event for bacterial killing but that a certain level of permeabilization is required in order to reach an intracellular target. However, irrespective of the mode of action, AMPs have to interact first with the bacterial surface and to pass the cell envelope, before they can reach the cytoplasmic membrane or translocate into the cytosol. Thereby, electrostatic interactions between the cationic peptides and negatively charged components of the cell wall such as lipopolysaccharides (LPS) in Gram-negative and teichoic acids in Gram-positive bacteria will modulate the attraction to the bacterial surface [27]. In this respect, there is an ongoing debate to which extent interaction with cell wall components including peptidoglycan may entrap AMPs or promote accumulation of AMPs on the cytoplasmic membrane [45]. Besides considering this aspect, we will also discuss antimicrobial activity related to inhibition of the biosynthesis of cell wall components and mechanisms related to direct membrane damage.

\subsection{AMPs Targeting Peptidoglycan}

The PGN sacculus is often designated as a mesh, which is relatively porous and does not represent a permeability barrier for particles of approximately $2 \mathrm{~nm}$ and globular hydrophilic molecules of a maximum size of about $50 \mathrm{kDa}$ that do not bind to PGN [133]. Note that most of the AMPs are between 15 and 50 amino acids, i.e., $<6 \mathrm{kDa}$. Further, PGN is not negatively charged and hence is not considered to significantly entrap cationic AMPs, thereby reducing their effective concentration at the membrane surface. This assumption is in line with a recent study showing that PGN binding of a synthetic antimicrobial peptide, OP-145, developed from a screen of the human cathelicidin LL-37, did not affect its membrane permeability as tested in leakage experiments using PG liposomes in the presence and absence of $0.1 \mathrm{wt} \%$ PGN [27].

Two peptides that exhibit strong partitioning toward the PGN mesh are the human cationic polypeptide ECP (eosinophilic cationic protein) [134] and omiganan, a derivative of the bovine cathelicidin indolicidin, which has been in a phase III clinical trial [135]. ECP is an antimicrobial RNase taking part in the eosinophile-mediated inflammatory processes. It is around 155 amino acids long of which 19 are arginine residues, which results in a high isoelectric point of 11.4 and high 
cationicity [136]. These properties further confer high affinity to negatively charged surfaces. In model studies, however, ECP induced only weak leakage of negatively charged lipid vesicles composed of either POPG or POPG/POPC at its bactericidal concentration toward S. aureus [137,138]. Moreover, electron micrographs did not reveal any damage of the cell wall and no detectable lysis of $S$. aureus in the presence of ECP [134]. Similarly, although fluorescence quenching studies yielded high partitioning constants of omiganan for anionic model membranes, the peptide failed to induce leakage of those lipid vesicles. Thus, as omiganan incorporates into anionic bilayers without inducing severe membrane perturbations, it was suggested that the peptide translocates through the membrane and acts on an intracellular target such as DNA as reported for indolicidin [139]. The same may be the case for ECP. However, it is not clear if both ECP and omiganan actually have intracellular targets and if binding to PGN triggers accumulation of the peptides, enhancing the cytosolic uptake.

\subsubsection{Inhibition of PGN Biosynthesis}

In contrast to many antibiotics that exhibit their antimicrobial activity via binding to and inhibition of enzymes involved in PGN biosynthesis, AMPs bind to peptidoglycan precursors and in turn interfere with further enzymatic processes resulting in inhibition of PGN synthesis by sterically hindering the activity of enzymes [140]. Examples include the branched tricyclic glycopeptide vancomycin, which was developed in the 1950s and serves as a gold standard for the treatment of methicillin resistant $S$. aureus infections [141], as well as families of cyclic lipo(glyco)peptides and lipoglycodepsipeptides like the macrocyclic ramoplanin derived as a mixture of three components from Actinoplanes sp. [140,142]. Ramoplanin comprises a 49-membered macrocyclic depsipeptide substituted with a disaccharide and a lipid side-chain [143]. The peptide contains 17 amino acids of which several are of D-configuration and two positively charged ornithine residues, which in addition to the ring structure, are essential for antimicrobial activity [144]. Initially, it was suggested that ramoplanin binds to lipid I inhibiting MurG glycosyltransferase and hence block the biosynthesis of the key precursor lipid II [145]. As it seemed unlikely that ramoplanin readily translocates to the cytosol to have direct access to the intracellular lipid I, it was a matter of debate whether direct inhibition of the MurG catalyzed conversion of lipid I to lipid II can occur [74,142,146]. Later studies confirmed the higher affinity of ramoplanin toward lipid II forming a 2:1 stoichiometric complex thereby inhibiting the periplasmic transglycosylation step of peptidoglycan biosynthesis (Figure 4) [147]. Recently, it was reported that the peptide also induces membrane depolarization of methicillin-susceptible $S$. aureus at or above its minimal bactericidal concentration and induces dramatic morphological changes. These observations correlated with cell viability and thus it was suggested that this mechanism may also contribute to the antimicrobial activity of ramoplanin [148]. It seems to be a common pattern that AMPs interfering with PGN biosynthesis also have the potential to damage the cytoplasmic membrane, which would make them superior to other antimicrobial compounds having only one specific target.

Of all peptides that inhibit PGN biosynthesis, lantibiotics are studied in most detail. A comprehensive description of the mode of action of nisin-like class A lantibiotics as well as merscacidin-like class B lantibiotics is given in an excellent recent review [149]. In brief, nisin derived from Lactococcus lactis consisting of 34 amino acids inhibits primarily PGN synthesis but also disrupts bacterial membranes (Figure 4) [150]. In particular, the A/B-ring of nisin forms a cage with the pyrophosphate moiety of lipid II in a 1:1 stoichiometric complex, a common binding mechanism for these kinds of lantibiotics [151,152]. After initial binding, four of these complexes assemble with four additional nisin molecules to form a stable transmembrane pore. Using derivatives of lipid II with shorter aliphatic residues demonstrated that the lipid tail is not important for peptide binding, but is important for pore formation [153]. Nisin disrupted pure anionic phospholipid model membranes only at much higher concentrations than necessary for bacterial killing. However, in the presence of lipid II these liposomes become much more susceptible to nisin emphasizing the specific complex formation [154]. As supported by a number of studies [149], it is obvious that the membrane bound PGN precursor lipid II acts as a docking moiety to attract the nisin to the bacterial membrane and to promote peptide insertion into the membrane 
leading to permeation $[155,156]$. Mersacidins including plantaricin $C$ have a different binding motif recognizing $\mathrm{N}$-acetylglucoseamine and hence can discriminate between lipid I and lipid II inhibiting the transglycosylation step in PGN biosynthesis [157].

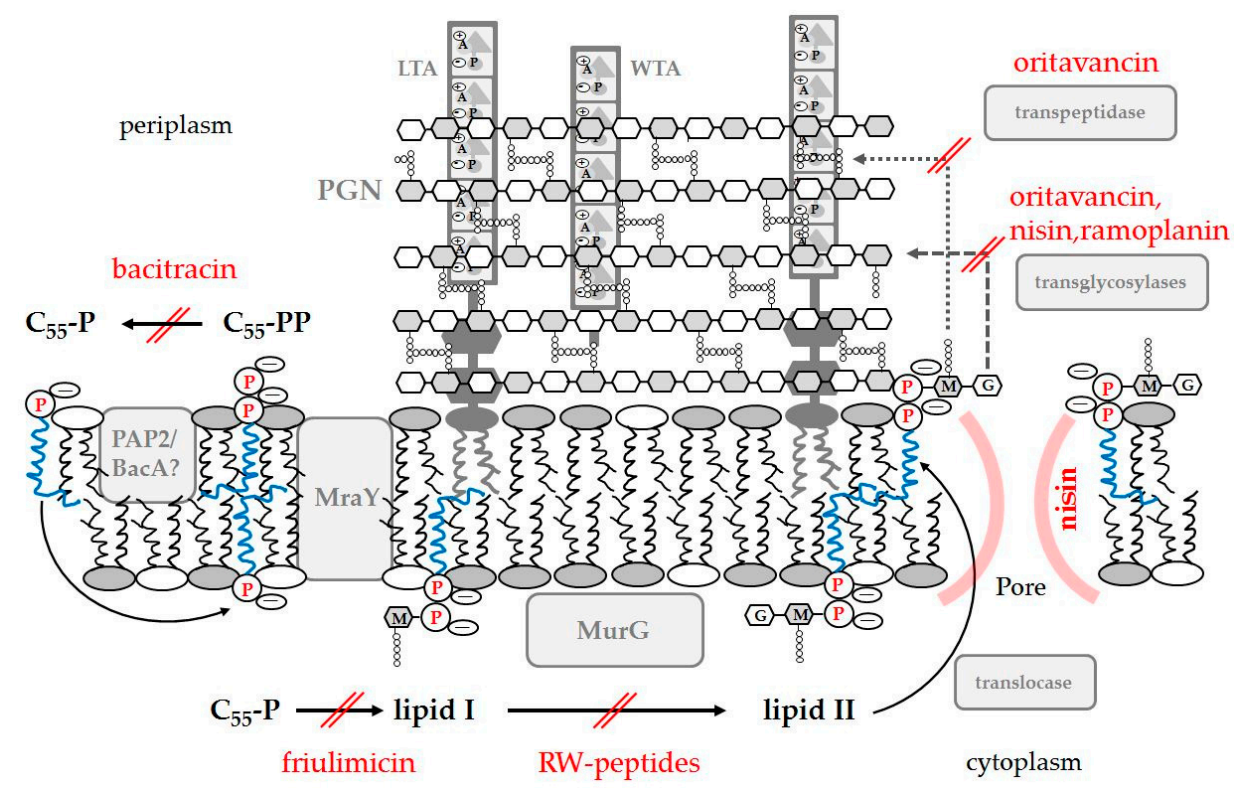

Figure 4. Proposed interaction sites of AMPs interfering with PGN biosynthesis. Nisin is typical of a number of lantibiotics and defensins that specifically bind to lipid II, though different binding motifs may apply. In addition, nisin can form a distinct peptide-lipid II pore indicated on the right hand side of the scheme. Short linear and cyclic RW-rich peptides are representative for peptides that delocalize peripheral membrane proteins like MurG, thereby interfering with physiological processes. Lipid II structure is simplified showing in addition to peptide and carbon chains the phosphate (P) with negative charges, $N$-acetylglucosoamine $(\mathrm{G})$ and $N$-acetylmuramic acid (M).

Oher peptides that share a similar mechanism of bacterial killing via lipid II targeting include defensins like human $\beta$-defensin 3, as well as the 11 amino acid depsipeptide teixobactin from the previous uncultured $\beta$-proteobacteria Eleftheria therrae, discussed in detail by Oppedijk et al. [149]. Targeting of lipid II was also observed by oyster defensins [158] and plectasin from the fungus Pseudoplectania nigrella [159]. Bacteria treated with oyster defensins accumulate the last soluble precursor of PGN, UDP-MurNAC pentapeptide without damaging the cytosolic membrane, suggesting that the peptides bind to lipid II after lipid II has been translocated to the outer leaflet of the cytoplasmic membrane [158]. Schmitt et al. [160,161] identified conserved residues involved in binding to lipid II of the structurally highly related plectasin and oyster defensins by comparing the sequences of these peptides. Phe2, Gly3, Cys4 and Cys25 were identified to be crucial for lipid II interaction and diversification at position 16 showed that the presence of positively charged residues improved the antimicrobial activity. The latter may be relevant for increased electrostatic interactions between defensins and the negatively charged membranes of bacteria [158]. This is consistent with their limited activity against Gram-negative bacteria, as lipid II is protected by the outer membrane preventing access of the oyster defensins to the periplasmic space and requires outer membrane damaging to become accessible in Gram-negative bacteria [158]. The same authors compared these with mammalian defensins, which have the same target lipid II. In contrast to oyster defensins mammalian defensins are active against both, Gram-negative and Gram-positive bacteria probably due to their membrane disruptive activity, which enables them to gain access to lipid II in Gram-negative bacteria.

Oritavancin, a semisynthetic lipoglycopeptide analogue of vancomycin, also displays a set of sequential mechanisms ranging from inhibition of PGN biosynthesis to perturbation of membrane 
integrity of Gram-positive organisms. Oritavancin binds to the alanine-alanine stem of the pentapeptide moiety of lipid II and also to the pentaglycyl bridging segment inhibiting PGN synthesis, thereby blocking transglycosylation and transpeptidation (Figure 4) [162]. In contrast to its analogue vancomycin, the 4'chlorobiphenyl group of oritavancin allows interaction with lipid II and cell membrane anchoring, which in addition results in perturbation of membrane integrity in S. aureus and E. faecalis [163]. Membrane depolarization in S. aureus following exposure to oritavancin was measured using the fluorescence indicator 3,3'-dipropylthiacarbocyanine [163,164]. Further, a "live and dead" assay, in which S. aureus living cells are stained with two fluorescent dyes, namely the membrane permeable Syto9 and membrane impermeable propidium iodide, showed that oritavancin treatment resulted in displacement of Syto9 by propidium iodide, which clearly indicates damage of the cell membrane resulting in increased permeability [164]. As well in model systems, oritavancin induced rapid leakage of liposomes composed of lipids extracted from S. aureus [165], CL/POPE and POPG/POPE [166]. It is tempting to speculate to which extent the ability of oritavancin to interact with phospholipids, to permeabilize those lipid vesicles at bactericidal concentration and to inhibit PGN biosynthesis contributes to its activity. In any case, such multiple facets of molecular mechanism are favorable to overcoming bacterial resistance. Thus, high-level oritavancin resistance has not yet been reported, neither in the laboratory nor in clinical studies [162,167].

Bacitracin, a common antibiotic used for the treatment of bacterial infections caused by Gram-positive bacteria, targets the $\mathrm{C}_{55}$-isoprenyl (undecaprenyl) pyrophosphate carrier $\left(\mathrm{C}_{55} \mathrm{PP}\right)$, another essential molecule in PGN biosynthesis. This antibiotic is a mixture consisting of cyclic polypeptides produced by Bacillus subtilis and Bacillus licheniformis. In contrast to most AMPs, the overall charge of bacitracin is neutral. The commercial products contain $70 \%$ bacitracin $\mathrm{A}$, a dodecapeptide of $1.4 \mathrm{kDa}$, which is the most potent, as well as an amphipathic one within the mixture that undergoes complexation with $\mathrm{C}_{55}-\mathrm{PP}$ in the presence of divalent metal ions [168]. The consequence is inhibition of de-phosphorylation of this carrier catalyzed by PAP2 (type 2 phosphatidic acid phosphatase) and BacA ( $\mathrm{C}_{55}$-PP phosphatase) and results in the inability of the cell to transport this carrier from the outer to the inner membrane leaflet necessary for the cell wall synthesis in the growing cell (Figure 4).

Finally, friulimicin is an antimicrobial lipopeptide that also requires divalent metal ions to build an antibiotic-metal-lipid complex. Also amphiphilic, friulimicin is produced by the actinomycete Actinoplanes friuliensis and exhibits excellent activity against Gram-positive pathogens. It consists of a macrocyclic decapeptide core and a lipid tail, interlinked by an exocyclic amino acid, and possesses an overall negative charge with amphipathicity increasing in the presence of calcium [169]. This peptide is supposed to form a complex with the cytosolic lipid carrier $\mathrm{C}_{55}-\mathrm{P}$ in the presence of calcium and to inhibit its conversion to lipid I mediated by Mra Y transferase (Figure 4) [169]. Friulimicin shares structural properties with the lipopeptide daptomycin from Streptomyces roseosporus, which is also negatively charged and selectively kills Gram-positive bacteria [170]. Although several membrane damaging mechanisms are proposed for the mode of action of daptomycin, it has not been excluded that aggregation of daptomycin in the membrane would interfere with membrane-associated processes including e.g., cell division (see Section 4.3).

\subsubsection{Binding to PGN: Recognition and Elimination of Pathogens}

Bacteria are detected by the innate immune system through a series of pattern recognition receptors. Peptidoglycan recognition proteins such as lectins and natural or semi-synthetic antibiotics like glycopeptides bearing unusual amino acids or modifications belong to pattern recognition molecules that target this unique cell wall component $[140,171,172]$. These evolutionary highly conserved proteins directly attack pathogens and induce an innate immune response, whereby binding to PGN initiates bacterial killing. Typical representatives of such proteins are $\sim 16 \mathrm{kDa}$ C-type lectins, which possess a characteristic globular structure with four functional domains. This functional region encompasses a carbohydrate binding domain, a neck repeat region of tandem 
helical repeats with exposed hydrophobic residues allowing oligomerization and a transmembrane domain as well as a cytosolic domain promoting internalization into the membrane [173]. Many of these proteins bind to PGN in a Ca-dependent manner, while human RegIII $\alpha$ (also known as HIP/PAP, hepatointestinal pancreatic/pancreatitis associated protein) recognizes the PGN backbone in a Ca-independent manner [172]. NMR studies showed that the Glu-Pro-Asn tripeptide motif located in the long loop region of human C-type lectins is essential for binding to PGN carbohydrate [172]. In RegIII $\alpha$, an exchange of the Glu residue in this motif by Gln prevents binding to PGN resulting in a reduced affinity to staphylococcal PGN and decreased antimicrobial activity against Gram-positive Listeria monocytogenes. Although the mechanism of bacterial killing by lectins is not fully understood, a recent publication demonstrated that RegIII $\alpha$ acts via formation of a membrane-penetrating pore [174]. While binding to PGN is crucial for attachment to bacteria, it is not necessary for subsequent pore formation, as shown for RegIII $\alpha$ that permeabilized membranes of non-spore forming Listeria monocytogenes and anionic phospholipid vesicles by forming a hexameric pore with a diameter of about $100 \AA$ [174]. Uncontrolled ion efflux and subsequent osmotic lysis resulted in bacterial killing. Interestingly, RegIII $\alpha$ has no activity toward Gram-negative bacteria, as LPS inhibits RegIII $\alpha$ membrane permeabilization and disruption of liposomes composed of $E$. coli total lipid extracts [174].

Although proteins such as C-type lectins are bigger in size and more complex in structure than the small AMPs, they still share basic functions like membrane disruption to kill pathogens. Similarly, the complement system of plasma proteins that are part of classical, alternative and lectin pathway acts as a rapid and efficient immune surveillance system by forming a membrane attack complex that results in direct osmotic lysis of cells $[175,176]$. Activation of one or another complement pathway is dependent on the membrane composition of the pathogen of which specific targets like charged patterns, array of repeating sugar residues, LPS, etc. are recognized and neutralized [176]. Thus, during evolution, nature has developed versatile strategies to recognize and eliminate pathogens.

\subsection{Teichoic Acid: Enhancing or Blocking AMP Activity}

Many AMPs that exhibit membrane disrupting properties like LL-37 [39,177], melittin and cecropin [178], also efficiently bind to teichoic acids [45,179]. Hence, there is an ongoing debate to which extent binding to wall or LTA hinders or promotes the interaction of AMPs with the cytoplasmic membrane $[27,45]$. Considering that the structure of LTA (e.g., from S. aureus) contains on average 24 glycerolphosphate repeating units of which each contains one negative charge from the phosphate group, it is obvious that LTA can potentially attract positively charged AMPs [179-181]. Therefore, it is not unlikely that AMPs may be entrapped by teichoic acids through increased peptide adsorption to these cell wall components, resulting in a decrease in local peptide concentration on the cytoplasmic membrane. In this context, it is of interest that it was shown that bacterial killing via membrane disruption only occurs when the membrane surface is completely saturated with AMPs [28]. Thus, trapping of peptides by LTA may sufficiently reduce the total concentration of peptides on the cytoplasmic membrane, preventing full membrane coverage and in turn membrane disruption. Reduction of the effective peptide concentration on the cytoplasmic membrane due to the presence of LTA can be deduced from studies on membrane mimetic systems with OP-145, a derivative of the human cathelicidin LL-37 [182]. Incorporation of LTA into POPG liposomes decreased the rate of leakage at a given lipid-to-peptide molar ratio, however, at very high peptide concentration full leakage was also achieved. The membrane permeability observed for those model systems was in the range of the effective lethal concentrations for S. aureus at 1.6-3.2 $\mu \mathrm{M}$. Therefore, it was proposed that the molecular mechanism of bacterial killing by OP-145 can still be explained by membrane perturbation [182]. Likewise, isolated LTA decreased the antimicrobial activity of the membrane damaging peptides LL-37 and mellitin [179]. A specific case is the antibacterial $7 \mathrm{kDa}$ polypeptide $B$ chain of $B$-bungarotoxin, the main presynaptic phospholipase $A_{2}$ neurotoxin from snake venom. Membrane damaging activity owing to its abundant positively charged amino acid residues was shown by calcein release from liposomes composed of binary mixtures of PG/PE and 
PG/CL, respectively [183]. However, when the peptide was pre-incubated with LTA, calcein release from PG/CL vesicles was completely abolished in agreement with the finding that the peptide was unable to inhibit growth or induce membrane permeability of $S$. aureus. Upon binding to LTA, circular dichroism spectra indicated that the peptide undergoes conformational changes resulting in inhibition of its active site that abrogates its membrane-damaging activity and inhibits its bactericidal activity toward S. aureus [184].

Another view of the same problem is that binding of AMPs to teichoic acids may initiate bacterial killing by mediating the entry of peptides towards the cytoplasmic membrane. In other words, by building a poly-anionic ladder, LTA and WTA may help poly-cationic peptides to traverse from the outside to the cytoplasmic membrane. Thereby, WTA extends beyond the PGN network, while LTA may not be able to reach past this layer [78]. Accordingly, Koprivnjak et al. [185] suggested that the killing activity of both the $14 \mathrm{kDa}$ mammalian group II phospholipase A2 (gIIA PLA ) $^{2}$ and the highly basic 45 amino acid human $\beta$-defensin 3 toward $S$. aureus depends on the initial electrostatic interaction with WTA, as the tagO mutant lacking WTA was selectively resistant to these AMPs. In contrast, negligible differences were observed in the lipase activity and binding of gIIA PLA 2 toward cell-wall depleted protoplasts from both wild type and tagO mutant of $S$. aureus suggesting that binding of gIIA PLA 2 to WTA is important to facilitate cell wall penetration and to gain access to the cytoplasmic membrane.

The impact of binding to teichoic acids on the antimicrobial activity of AMPs can also be deduced from a common resistance mechanism of Gram-positive bacteria, which is D-alanylation of the LTA glycerolphosphates $[82,186]$ to reduce the overall negative charge on the surface, lowering the affinity to cationic molecules like AMPs. Indeed, reduction of the D-alanyl content of the cell wall increases the susceptibility to AMPs [187-190]. Accordingly, depletion of D-alanylester from teichoic acid in dlt mutants from gallidermin-sensitive $S$. aureus resulted in increased susceptibility to positively charged AMPs such as defensins, protegrins, magainin and diverse lantibiotics but not to neutral gramicidin B. This finding indicates the importance of electrostatic interactions between S. aureus and AMPs [189]. In group B Streptococci, however, D-alanylation showed little influence on the surface-association of fluorescently-labeled AMPs [191], which suggests that charge effects are not solely responsible for the observed changes in susceptibility to AMPs. Here, the protective effect was explained by the increased cell wall density observed in strains with D-alanylation preventing penetration of cationic AMPs.

\subsubsection{Direct Killing by Binding to LTA}

Finally, another bactericidal protein, the phospholipoglycoprotein vitellogenin, which is a major precursor of the yolk proteins in oviparous organisms, kills bacteria via binding to LTA and not via membrane disruption [181]. Results from scanning electron microscopy demonstrated that $450 \mathrm{kDa}$ vitellogenin from the fish Hexagrammos otakii causes damage of the cell wall of S. aureus whole cells with the appearance of collapsed architecture, but does not alter the morphology of cell wall deficient S. aureus protoplasts. Severe cell lysis by vitellogenin was only observed for S. aureus whole cells, but not in cell wall depleted protoplasts. In addition, destroying of $S$. aureus cell-wall is abolished, when vitellogenin was pre-incubated with LTA before applying to $S$. aureus, which concomitantly resulted in loss of antibacterial activity of the peptide. These observations suggest that the binding of vitellogenin to LTA is lethal to S. aureus rather than attacking the plasma membranes [181]. In addition, vitellogenin may act as a multivalent pattern recognition molecule capable of binding to LTA, lipopolysaccharide, glucan and virons [192], as also suggested for vitellogenin from scallops [193].

\subsection{Interaction of AMPs with the Cytoplasmic Membrane}

As mentioned earlier, a large number of AMPs supposedly target the cytoplasmic membrane leading to membrane disruption and/or disorder and consequently to bacterial death. So far, there is consensus that the very distinct lipid composition of bacterial and mammalian cytoplasmic membranes mainly manifested as differences in surface charge and bilayer fluidity favors binding of cationic 
AMPs to the anionic bacterial membrane, thus allowing AMPs to discriminate between bacteria and host cells [30,47]. In addition, hydrophobic effects have to be considered not only for membrane partitioning but also for binding [194]. Thus, the physicochemical properties of AMPs especially their amphipathicity determine their membrane activity [46]. In the majority of cases, the mechanisms of membrane perturbation at a molecular level are not yet clear, although numerous models exist to explain the membrane damaging activities of AMPs [195]. In general, however, the mode of action of AMPs is mostly discussed within the framework of the carpet [196] or pore model [197].

One example is alamethicin, a 20 residue amphipathic $\alpha$-helical peptide derived from Trichoderma viride, which contains non-proteinogenic amino acid residues and which due to the glutamic acid at position 18 has a net negative charge at $\mathrm{pH} 7$ [198]. Its high activity against Gram-positive bacteria but negligible activity against Gram-negative bacteria was attributed to the hydrophobicity of the peptide, which may prevent translocation of the peptide across the outer membrane to reach the cytoplasmic membrane of Gram-negative bacteria [48]. The high bactericidal activity of alamethicin against mollicutes, which do not have complex cell wall architecture, would be in line with this argument [48]. On a molecular level, a barrel-stave type pore was proposed from neutron and X-ray analysis of oriented membrane model systems [199] and recently directly visualized using high resolution electrochemical scanning tunneling microscopy [200]. At low concentrations, alamethicin aligns parallel at the membrane surface, but at a certain threshold concentration inserts perpendicular into the lipid bilayer forming a transmembrane pore. This barrel-stave type pore consists of eight monomers, where the hydrophobic face of alamethicin is oriented toward the hydrophobic core of the membrane and the hydrophilic face toward the pore lumen [201]. Huang's group investigated a number of naturally occurring peptides including magainins, melittin and protegrins, but only found the barrel-stave type pore for alamethicin [202]. The other peptides appear to induce a toroidal pore, in which AMPs together with the lipid form a water-filled pore in a way that the lipid monolayer bends continuously through the pore so that the water core is lined by both the peptides and the lipid headgroups $[197,203]$. It should be noted however that these experiments were performed using PC and PC/PG, respectively, which may not represent the most appropriate bacterial mimetic system.

Apart from membrane disruption by formation of a pore complex between AMPs and lipid II as described above, there is no membrane-disrupting mechanism that could be considered to be typical for Gram-positive bacteria. The molecular mode of action discussed for AMPs to disrupt membranes such as the carpet model [196], detergent-like [204] or interfacial activity [205] can be relevant for both, Gram-positive and Gram-negative bacteria. Therefore, we focus our discussion on experiments that are directly related to membrane effects in Gram-positive bacteria and on those aspects that might make a certain molecular mechanism more likely to occur in Gram-positive bacteria.

\subsubsection{Lipid Segregation and Alteration of Membrane Domains as a Mode of Action of AMPs}

Interaction of AMPs with specific membrane domains, which are involved in bacterial cell differentiation, cell division and protein secretion, has been also reported for cationic AMPs. For example, in E. faecalis at sub-inhibitory concentrations human $\beta$-defensin 2 disrupted the localization of SecA ATP translocase and sortase SrtA, which play a role in the attachment of virulence factors occurring at spatially restricted domains containing anionic lipids [206]. Similar effects were found upon incubation of $S$. pyogenes with sub-inhibitory concentrations of the human neutrophil peptide 1 and polymyxin B [207]. These observations suggest that disruption of the assembly of virulence factor may be an additional mode of action of AMPs. Further evidence that cationic AMPs target membrane domains enriched in anionic lipids comes from studies both on model systems and bacterial cells. For instance, cecropin A [208] as well as $N$-acyl derivatives from lactoferricin [209] remodeled PE/CL domains present at the septum and poles of E. coli resulting in cell division defects. Preferred partitioning into PE/CL mixtures was also demonstrated for cyclic RW-rich hexapeptides, which was governed rather by hydrophobic than electrostatic effects [210,211]. Again, the results from the membrane mimics were in agreement with fluorescence staining experiments of $B$. subtilis membranes, which 
revealed that the short peptide interfered with the CL-enriched domain organization at septum and pole [211]. The central role of these negative intrinsic curvature lipids for cell division is to provide the proper lipid packing constraints at the division site and the cell poles $[107,212,213]$. Furthermore, localization of proteins that regulate the division plane such as MinD and MinE to E. coli membrane is CL and PG dependent [214]. Thus, it was proposed that anchoring of those proteins and other peripheral membrane proteins might be disturbed owing to the altered domain organization by the hexapeptide [211]. This assumption is supported by studies on linear RW-rich hexapeptides, which demonstrated that these peptides dislocate peripheral membrane proteins such as MurG (Figure 4) and cytochrome $\mathrm{c}$ in membranes of B. subtilis interfering with cell wall biosynthesis and energy metabolism, respectively [215,216]. Again, this was attributed to preferential interaction with PG leading to a change in membrane domain organization. The same phenomena were observed with the cyclic peptide gramicidin S. Therefore, specific interaction of AMPs with anionic lipids will have important implications for the structure and integrity of membranes and hence influence the function of membrane proteins adversely affecting viability of bacteria.

In model systems, lateral phase separation in bilayers composed of anionic and zwitterionic lipids has been demonstrated for a number of cationic AMPs because of their preferential binding to the negatively charged lipid components [31,217-221]. Although phase separation was also observed for mono-component systems, i.e., formation of peptide-poor and peptide-rich domains [32,182], promotion of lateral phase separation has been mainly investigated using PE/PG and PE/CL mixtures. Laterally, heterogeneous domains with a preferred location of AMPs in one domain will differ significantly in their properties with respect to membrane thickness, fluidity and curvature strain. Consequently, at the boundary of these domains, packing defects will occur, which will lower the membrane permeability barrier representing a general mode of action of AMPs, in addition to interfering with membrane structure and organization $[29,30,44]$. Lateral phase separation has been specifically proposed as a mechanism contributing to the antimicrobial activity of a designed $\alpha / \beta$ peptide [222] and an oligo-acyl-lysine (OAKs) compound [223,224]. Further studies indicated that lipid segregation is not primarily dependent on the nature of the anionic headgroup and acyl chain [223]. This correlates with findings that the inhibitory activity of short OAK peptides against Gram-positive bacteria was dependent on the fraction of anionic phospholipids in the cytoplasmic membrane, i.e., it was high against staphylococci, streptococci and enterococci but low for listeria and bacilli [225]. Notably, a study on the interaction of different cyclic hexapeptides with PE/PG lipid membranes showed that in addition to electrostatic binding, distinct positioning of the three hydrophobic amino acids also contributed to binding affinity and in particular to the extent of induction of lipid phase separation, which correlated with antimicrobial activity [210]. Clustering of anionic lipids was shown to be most effective for substances with sequential positive charges contained within a flexible molecule that can adapt to the distances of charged groups on the surface of the bacterial cell membrane [226]. This implies for the design of AMPs that peptides with sequences rich in cationic residues and conformational flexibility will be most prone to act via such a mechanism $[221,226]$.

\subsubsection{A Role Model for AMPs: The Multifaceted Actions of Daptomycin}

Pore formation, though less defined, was also suggested for the cyclic lipopeptide daptomycin from Streptomyces roseosporus, which selectively kills Gram-positive bacteria including methicillin-resistant S. aureus and vancomycin-resistant Enterococcus [170]. In the presence of calcium daptomycin, which at neutral $\mathrm{pH}$ has a net negative charge of three, forms micellar aggregates in aqueous solutions. Upon interaction with membranes, these micelles may need to dissociate before the peptides insert in the outer leaflet of the bilayer. This process is facilitated by calcium, which strongly binds to negatively charged lipid headgroups. It was suggested that insertion of daptomycin may be accompanied again by oligomerization inducing a positive curvature strain on the membrane phospholipids to form a pore and in turn leakage of potassium from the bacterial cell leading to loss of membrane potential, dysfunction of macromolecular synthesis and finally to cell death [170,227-229]. In general, 
promotion of positive curvature strain was suggested to play a role in toroidal pore formation, but may be also involved in micellization of a bilayer [230]. However, when CL was added at molar fractions of 10-20 mol \% to PG liposomes, pore formation was prevented [231]. This finding was explained by different penetration depths of daptomycin in PG and PG/CL mixtures (Figure 5). Thereby, the extra bulk in the acyl chain layer of CL should enable deeper penetration of the oligomeric daptomycin complex avoiding the creation of voids in the hydrophobic core. Voids are energetically unfavorable and can be compensated by increased trans-gauche isomerization of the acyl chains (increase of disorder), moving of the inner bilayer leaflet towards the outer (interdigitation) or bending of the leaflets (curvature induction) $[29,44,232,233]$. If latter is the case, as proposed for the system daptomycin/PG, positive curvature induction would result in the formation of a half-toroidal structure [231]. The authors argue further that this should enable the oligomeric peptide complex to flip to the inner leaflet and then combine with a second complex in the outer leaflet to form the final pore (Figure 5). Thus, it may be also conceivable that CL, which in particular in the presence of calcium adopts lipid structures of negative curvature [103], counteracts the positive curvature needed for such a pore formation. In fact, such a model includes important phenomena such as induction of curvature strain and membrane thinning owing to increased acyl chain disorder or interdigitation as observed for a number of AMPs. For example, $\alpha$-helical peptides that align parallel to the membrane surface such as the bee venom toxin melittin, the frog skin antimicrobial peptide PGLa, human cathelicidin LL-37 and its derivative OP-145 are prone to induce interdigitation [182,234]. The impact of void formation and thus bilayer destabilization was demonstrated by varying both the nature of headgroup to modulate the depth of peptide penetration (less for anionic lipids) and acyl chain length to modulate the possible volume of void formation (the longer the chain the larger the void) [234]. This kind of membrane perturbation may be more relevant for Gram-positive bacteria because of the larger fraction of anionic membrane lipids. Induction of curvature strain that even led to gross morphological changes, i.e., formation of cubic lipid aggregates, was reported for lipid extracts from A. laidlawii in the presence of the cyclic decapeptide gramicidin S [230,235].

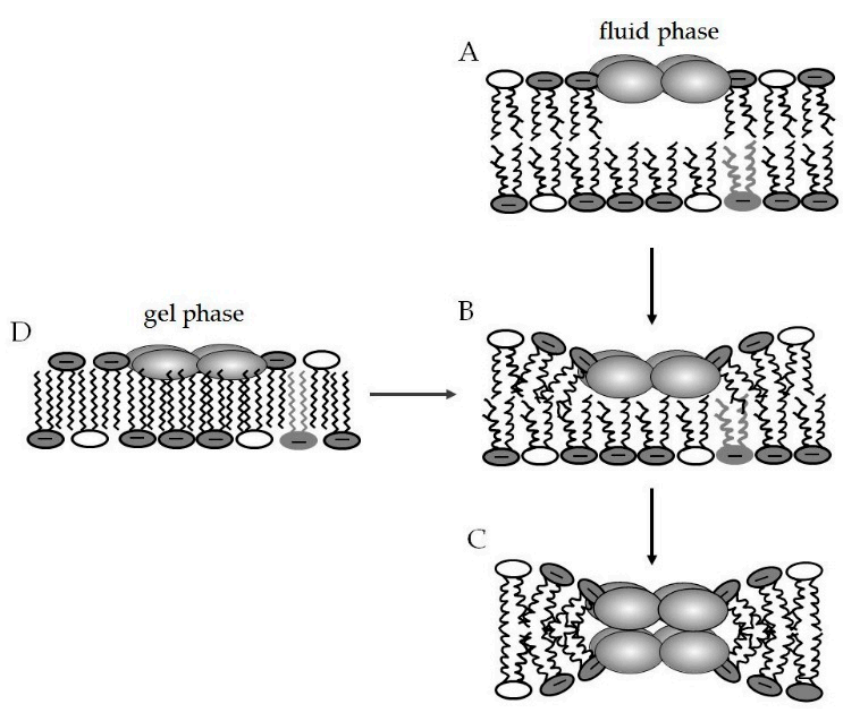

Figure 5. Scheme of proposed pore formation of daptomycin modified from [231]. Insertion of the peptide in the membrane interface and oligomerization creates a void in the hydrophobic core (A) inducing local positive curvature accompanied by deeper penetration of the peptide complex (B). This results in a dimple formation with a locally strongly decreased membrane thickness [236]. The oligomeric daptomycin may flip to the inner membrane leaflet and eventually combine with a complex of the outer leaflet to form a toroidal pore (C). Note, in the gel phase the void can be compensated by interdigitation of the lipid's acyl chains (D) as shown for several AMPs [234]. 
A completely new view on the mode of action of daptomycin was presented in a very recent study [237]. Using giant unilamellar vesicles, evidence was provided that above the threshold concentration the peptide exerts a lipid extracting effect. Like in the other studies, this phenomenon was only observed when the vesicles contained PG and when calcium was present. Moreover, the extra-membranous aggregates appeared to be similar to the direct action of daptomycin on bacterial membranes [238]. Interestingly, similar observations were reported from amphotericin B that presumably kills yeast by extracting ergosterol from lipid bilayers [239]. It was suggested that such a mechanism may also apply to other membrane-active compounds such as AMPs [240]. Chen et al. [237] stressed, however, that the lipid extracting effect of daptomycin was inadequate to explain effects related to $\mathrm{CL}$, which indicates that daptomycin may have various membrane targets.

This assumption is strongly supported by the kind of mutations that confer resistance to daptomycin, which were found to be related to lipid synthesis, e.g., mutants being defective in synthesizing lysyl-PG (mprF) in S. aureus [241], cardiolipin-synthase (cls) in E. faecalis [242] or phosphatidylglycerol-synthase ( $p g s A)$ in B. subtillis [243]. In fact, it was shown that binding of daptomycin to PG-rich membrane domains in B. subtilis results in delocalization of the cell division protein DivIVA [238]. As a consequence, dramatic cell wall and membrane defects lead to anomalous cell morphology and eventually to membrane disruption. Further, it is known that DivIVA preferentially locates in membrane regions of high curvature [244] and hence it was assumed that membrane domains formed by daptomycin are characterized by such a curvature. This may also explain the strong association of daptomycin with the bacterial division septum by its preferential insertion into the leading edges of highly curved septal and forespore membranes [238]. Furthermore, in E. faecalis, daptomycin also interacts with the division septum, which correlates with the presence of CL domains [245]. Altered targeting was found in daptomycin-resistant E. faecalis, where a point mutation in LiaF that senses AMPs and regulates CL septal localization, leads to redistribution of CL away from the division septum, thus preventing daptomycin from binding to this region.

In summary, although the exact molecular mechanisms of action of daptomycin are still disputed, this clearly exemplifies that AMPs may interfere with membrane structure and membrane function at various levels by different means. Thus, AMPs may induce (i) membrane permeabilization; (ii) disrupt membrane domain organization and (iii) delocalize peripheral membrane proteins, which may make such peptides superior to antibiotics that act only on one specific target.

Acknowledgments: This work was supported by the Austrian Science Fund FWF, Project No. I 1763-B21 (to K.L.) and European Community's Seventh Framework Program (FP7/2007-2013) under grant agreement $n^{\circ} 278890$ (BALI Consortium).

Author Contributions: N.M. conceived and designed the concept of the review and wrote the majority of it. K.L. helped in all aspects of the writing and contributed significantly to knowledge of antimicrobial peptides and their mode of action. Both authors proofread and edited the manuscript.

Conflicts of Interest: The authors declare no conflict of interest.

\section{Abbreviations}

The following abbreviations are used in this manuscript:

$\begin{array}{ll}\text { AMPs } & \text { antimicrobial peptides } \\ \text { CL } & \text { cardiolipin } \\ \text { DPPE } & \text { 1,2-dipamitoyl-sn-glycero-3-phospho-rac-ethanolamine } \\ \text { DPPG } & \text { 1,2-dipamitoyl-sn-glycero-3-phospho-rac-glycerol } \\ \text { LPS } & \text { Lipopolysaccharide } \\ \text { LTA } & \text { lipoteichoic acid } \\ \text { LUV } & \text { large unilamellar vesicle } \\ \text { lysyl-PG } & \text { lysyl-phosphatidylglycerol } \\ \text { MLVs } & \text { multilamellar vesicles } \\ \text { NAM } & \text { N-acetyl glucosamine } \\ \text { NAG } & \text { N-acetyl muramic acid } \\ \text { PA } & \text { phosphatidic acid } \\ \text { PC } & \text { phosphatidylcholine }\end{array}$


PE

PGN

POPC

POPE

POPG

PS

PI

WTA phosphatidylethanolamine

peptidoglycan

1-palmitoyl-2-oleoyl-sn-glycero-3-phosphocholine

1-palmitoyl-2-oleoyl-sn-glycero-3-phospho-rac-ethanolamine

1-palmitoyl-2-oleoyl-sn-glycero-3-phospho-rac-glycerol

phosphatidylserine

phosphatidylinositol

wall teichoic acid

\section{References}

1. World Health Organization. Antimicrobial Resistance Global Report on Surveillance: 2014 Summary; WHO: Geneva, Switzerland, 2014.

2. Fish, D.N. Optimal antimicrobial therapy for sepsis. Am. J. Health Syst. Pharm. 2002, 59, S13-S19. [PubMed]

3. Linder, K.E.; Nicolau, D.P.; Nailor, M.D. Predicting and preventing antimicrobial resistance utilizing pharmacodynamics: Part I Gram positive bacteria. Expert Opin. Drug Metab. Toxicol. 2016, 12, $267-280$. [CrossRef] [PubMed]

4. Kali, A.; Charles, M.V.; Srirangaraj, S. Cadazolid: A new hope in the treatment of Clostridium difficile infection. Australas. Med. J. 2015, 8, 253-262. [CrossRef] [PubMed]

5. Edelsberg, J.; Weycker, D.; Barron, R.; Li, X.; Wu, H.; Oster, G.; Badre, S.; Langeberg, W.J.; Weber, D.J. Prevalence of antibiotic resistance in US hospitals. Diagn. Microbiol. Infect. Dis. 2014, 78, 255-262. [CrossRef] [PubMed]

6. Camargo, A.C.; Woodward, J.J.; Nero, L.A. The Continuous Challenge of Characterizing the Foodborne Pathogen Listeria monocytogenes. Foodborne Pathog. Dis. 2016, 13, 405-416. [CrossRef] [PubMed]

7. Cannon, J.P.; Lee, T.A.; Bolanos, J.T.; Danziger, L.H. Pathogenic relevance of Lactobacillus: A retrospective review of over 200 cases. Eur. J. Clin. Microbiol. Infect. Dis. 2005, 24, 31-40. [CrossRef] [PubMed]

8. World Health Organization. Global Tuberculosis Report 2014; WHO Press: Geneva, Switzerland, 2014.

9. World Health Organization. Global Tuberculosis Report 2015; WHO Press: Geneva, Switzerland, 2015.

10. Gutsmann, T. Interaction between antimicrobial peptides and mycobacteria. Biochim. Biophys. Acta Biomembr. 2016, 1858, 1034-1043. [CrossRef] [PubMed]

11. Lohner, K. Development of Novel Antimicrobial Agents: Emerging Strategies; Horizon Scientific Press: Wymondham, UK, 2001; p. 270.

12. Boman, H.G. Antibacterial peptides: Basic facts and emerging concepts. J. Intern. Med. 2003, 254, $197-215$. [CrossRef] [PubMed]

13. Marr, A.K.; Gooderham, W.J.; Hancock, R.E. Antibacterial peptides for therapeutic use: Obstacles and realistic outlook. Curr. Opin. Pharmacol. 2006, 6, 468-472. [CrossRef] [PubMed]

14. Steckbeck, J.D.; Deslouches, B.; Montelaro, R.C. Antimicrobial peptides: New drugs for bad bugs? Expert Opin. Biol. Ther. 2014, 14, 11-14. [CrossRef] [PubMed]

15. Lohner, K.; Staudegger, E. Are we on the threshold of the post-antibiotic era? In Development of Novel Antimicrobial Agents: Emerging Strategies; Lohner, K., Ed.; Horizon Scientific Press: Wymondham, UK, 2001; pp. 1-15.

16. Wang, G.; Li, X.; Wang, Z. APD2: The updated antimicrobial peptide database and its application in peptide design. Nucleic Acids Res. 2009, 37, D933-D937. [CrossRef] [PubMed]

17. Gonzalez-Ruiz, A.; Seaton, R.A.; Hamed, K. Daptomycin: An evidence-based review of its role in the treatment of Gram-positive infections. Infect. Drug Resist. 2016, 9, 47-58. [PubMed]

18. Brade, K.D.; Rybak, J.M.; Rybak, M.J. Oritavancin: A New Lipoglycopeptide Antibiotic in the Treatment of Gram-Positive Infections. Infect. Dis. Ther. 2016, 5, 1-15. [CrossRef] [PubMed]

19. Ganz, T.; Lehrer, R.I. Antimicrobial peptides in innate immunity. In Development of Novel Antimicrobial Agents: Emerging Strategies; Lohner, K., Ed.; Horizon Scientific Press: Wymondham, UK, 2001; pp. 139-147.

20. Hancock, R.E. Cationic peptides: effectors in innate immunity and novel antimicrobials. Lancet Infect. Dis. 2001, 1, 156-164. [CrossRef]

21. Zasloff, M. Antimicrobial peptides of multicellular organisms. Nature 2002, 415, 389-395. [CrossRef] [PubMed]

22. Nguyen, L.T.; Haney, E.F.; Vogel, H.J. The expanding scope of antimicrobial peptide structures and their modes of action. Trends Biotechnol. 2011, 29, 464-472. [CrossRef] [PubMed] 
23. Steinstraesser, L.; Kraneburg, U.; Jacobsen, F.; Al-Benna, S. Host defense peptides and their antimicrobial-immunomodulatory duality. Immunobiology 2011, 216, 322-333. [CrossRef] [PubMed]

24. Hancock, R.E.; Sahl, H.G. Antimicrobial and host-defense peptides as new anti-infective therapeutic strategies. Nat. Biotechnol. 2006, 24, 1551-1557. [CrossRef] [PubMed]

25. Mansour, S.C.; Pena, O.M.; Hancock, R.E. Host defense peptides: Front-line immunomodulators. Trends Immunol. 2014, 35, 443-450. [CrossRef] [PubMed]

26. Fjell, C.D.; Hiss, J.A.; Hancock, R.E.; Schneider, G. Designing antimicrobial peptides: Form follows function. Nat. Rev. Drug Discov. 2012, 11, 37-51.

27. Malanovic, N.; Lohner, K. Gram-positive bacterial cell envelopes: The impact on the activity of antimicrobial peptides. Biochim. Biophys. Acta Biomembr. 2016, 1858, 936-946. [CrossRef] [PubMed]

28. Roversi, D.; Luca, V.; Aureli, S.; Park, Y.; Mangoni, M.L.; Stella, L. How many antimicrobial peptide molecules kill a bacterium? The case of PMAP-23. ACS Chem. Biol. 2014, 9, 2003-2007. [CrossRef] [PubMed]

29. Lohner, K. New strategies for novel antibiotics: Peptides targeting bacterial cell membranes. Gen. Physiol. Biophys. 2009, 28, 105-116. [CrossRef] [PubMed]

30. Lohner, K.; Blondelle, S.E. Molecular mechanisms of membrane perturbation by antimicrobial peptides and the use of biophysical studies in the design of novel peptide antibiotics. Comb. Chem. High Throughput Screen 2005, 8, 241-256.

31. Lohner, K.; Latal, A.; Lehrer, R.I.; Ganz, T. Differential scanning microcalorimetry indicates that human defensin, HNP-2, interacts specifically with biomembrane mimetic systems. Biochemistry 1997, 36, 1525-1531. [CrossRef] [PubMed]

32. Latal, A.; Degovics, G.; Epand, R.F.; Epand, R.M.; Lohner, K. Structural aspects of the interaction of peptidyl-glycylleucine-carboxyamide, a highly potent antimicrobial peptide from frog skin, with lipids. Eur. J. Biochem. 1997, 248, 938-946. [CrossRef] [PubMed]

33. Lee, D.K.; Bhunia, A.; Kotler, S.A.; Ramamoorthy, A. Detergent-type membrane fragmentation by MSI-78, MSI-367, MSI-594, and MSI-843 antimicrobial peptides and inhibition by cholesterol: A solid-state nuclear magnetic resonance study. Biochemistry 2015, 54, 1897-1907. [CrossRef] [PubMed]

34. Matsuzaki, K.; Sugishita, K.; Fujii, N.; Miyajima, K. Molecular basis for membrane selectivity of an antimicrobial peptide, magainin 2. Biochemistry 1995, 34, 3423-3429. [CrossRef] [PubMed]

35. Wang, G. Structures of human host defense cathelicidin LL-37 and its smallest antimicrobial peptide KR-12 in lipid micelles. J. Biol. Chem. 2008, 283, 32637-32643. [CrossRef] [PubMed]

36. Porcelli, F.; Verardi, R.; Shi, L.; Henzler-Wildman, K.A.; Ramamoorthy, A.; Veglia, G. NMR structure of the cathelicidin-derived human antimicrobial peptide LL-37 in dodecylphosphocholine micelles. Biochemistry 2008, 47, 5565-5572. [CrossRef] [PubMed]

37. Porcelli, F.; Buck-Koehntop, B.A.; Thennarasu, S.; Ramamoorthy, A.; Veglia, G. Structures of the dimeric and monomeric variants of magainin antimicrobial peptides (MSI-78 and MSI-594) in micelles and bilayers, determined by NMR spectroscopy. Biochemistry 2006, 45, 5793-5799. [CrossRef] [PubMed]

38. Haney, E.F.; Hunter, H.N.; Matsuzaki, K.; Vogel, H.J. Solution NMR studies of amphibian antimicrobial peptides: Linking structure to function? Biochim. Biophys. Acta Biomembr. 2009, 1788, 1639-1655. [CrossRef] [PubMed]

39. Henzler Wildman, K.A.; Lee, D.K.; Ramamoorthy, A. Mechanism of lipid bilayer disruption by the human antimicrobial peptide, LL-37. Biochemistry 2003, 42, 6545-6558. [CrossRef] [PubMed]

40. Bechinger, B. The structure, dynamics and orientation of antimicrobial peptides in membranes by multidimensional solid-state NMR spectroscopy. Biochim. Biophys. Acta Biomembr. 1999, 1462, 157-183. [CrossRef]

41. Bechinger, B.; Resende, J.M.; Aisenbrey, C. The structural and topological analysis of membrane-associated polypeptides by oriented solid-state NMR spectroscopy: Established concepts and novel developments. Biophys. Chem. 2011, 153, 115-125. [CrossRef] [PubMed]

42. Strandberg, E.; Kanithasen, N.; Tiltak, D.; Burck, J.; Wadhwani, P.; Zwernemann, O.; Ulrich, A.S. Solid-state NMR analysis comparing the designer-made antibiotic MSI-103 with its parent peptide PGLa in lipid bilayers. Biochemistry 2008, 47, 2601-2616. [CrossRef] [PubMed]

43. Wang, G.; Mishra, B.; Epand, R.F.; Epand, R.M. High-quality 3D structures shine light on antibacterial, anti-biofilm and antiviral activities of human cathelicidin LL-37 and its fragments. Biochim. Biophys. Acta Biomembr. 2014, 1838, 2160-2172. [CrossRef] [PubMed] 
44. Lohner, K. Membrane-active antimicrobial peptides as template structures for novel antibiotic agents. Curr. Top. Med. Chem. 2016, in press.

45. Melo, M.N.; Ferre, R.; Castanho, M.A. Antimicrobial peptides: Linking partition, activity and high membrane-bound concentrations. Nat. Rev. Microbiol. 2009, 7, 245-250. [CrossRef] [PubMed]

46. Findlay, B.; Zhanel, G.G.; Schweizer, F. Cationic amphiphiles, a new generation of antimicrobials inspired by the natural antimicrobial peptide scaffold. Antimicrob. Agents Chemother. 2010, 54, 4049-4058. [CrossRef] [PubMed]

47. Henderson, J.M.; Lee, K.Y.C. Promising antimicrobial agents designed from natural peptide templates. Curr. Opin. Solid State Mater. Sci. 2013, 17, 175-192. [CrossRef]

48. Leitgeb, B.; Szekeres, A.; Manczinger, L.; Vagvolgyi, C.; Kredics, L. The history of alamethicin: A review of the most extensively studied peptaibol. Chem. Biodivers. 2007, 4, 1027-1051. [CrossRef] [PubMed]

49. O'Leary, W.M.; Wilkinson, D.A. Gram-positive bacteria. In Microbial Lipids, 1st ed.; Ratledge, C., Wilkinson, S.G., Eds.; Academic Press: London, UK, 1988; Volume 1, pp. 117-201.

50. Wilkinson, S.G. Gram-negative bacteria. In Microbial Lipids, 1st ed.; Ratledge, C., Wilkinson, S.G., Eds.; Academic Press: London, UK, 1988; Volume 1, pp. 299-488.

51. Vollmer, W.; Holtje, J.V. The architecture of the murein (peptidoglycan) in Gram-negative bacteria: Vertical scaffold or horizontal layer(s)? J. Bacteriol. 2004, 186, 5978-5987. [CrossRef] [PubMed]

52. Rogers, H.J.; Perkins, H.R.; Ward, J.B. Membranes of bacteria lacking peptidoglycan. In Microbial Cell Walls and Membranes; Rogers, H.J., Perkins, H.R., Ward, J.B., Eds.; Springer: Dordrecht, The Netherlands, 1980; pp. 176-189.

53. Hayami, M.; Okabe, A.; Kariyama, R.; Abe, M.; Kanemasa, Y. Lipid-composition of Staphylococcus aureus and its derived L-forms. Microbiol. Immunol. 1979, 23, 435-442. [CrossRef] [PubMed]

54. White, D.A.; Frerman, F.E. Fatty Acid Composition of the complex lipids of Staphylococcus aureus During the Formation of the Membran-bound Electron Transport System. J. Bacteriol. 1968, 95, 2198-2209.

55. Mishra, N.N.; Bayer, A.S.; Tran, T.T.; Shamoo, Y.; Mileykovskaya, E.; Dowhan, W.; Guan, Z.; Arias, C.A. Daptomycin resistance in enterococci is associated with distinct alterations of cell membrane phospholipid content. PLoS ONE 2012, 7, e43958. [CrossRef] [PubMed]

56. Chiu, T.H.; Hung, S.A. Effect of age on the membrane lipid composition of Streptococcus sanguis. Biochim. Biophys. Acta Biomembr. 1979, 558, 267-272. [CrossRef]

57. Fozo, E.M.; Kajfasz, J.K.; Quivey, R.G. Low pH-induced membrane fatty acid alterations in oral bacteria. FEMS Microbiol. Lett. 2004, 238, 291-295. [CrossRef] [PubMed]

58. Trombe, M.C.; Laneelle, M.A.; Laneelle, G. Lipid composition of aminopterin-resistant and sensitive strains of Streptococcus pneumoniae. Effect of aminopterin inhibition. Biochim. Biophys. Acta Biomembr. 1979, 574, 290-300.

59. Nampoothiri, K.M.; Hoischen, C.; Bathe, B.; Mockel, B.; Pfefferle, W.; Krumbach, K.; Sahm, H.; Eggeling, L. Expression of genes of lipid synthesis and altered lipid composition modulates L-glutamate efflux of Corynebacterium glutamicum. Appl. Microbiol. Biotechnol. 2002, 58, 89-96. [CrossRef] [PubMed]

60. Hoischen, C.; Kramer, R. Membrane-alteration is necessary but not sufficient for effective glutamate secretion in Corynebacterium glutamicum. J. Bacteriol. 1990, 172, 3409-3416. [PubMed]

61. Hoischen, C.; Gura, K.; Luge, C.; Gumpert, J. Lipid and fatty acid composition of cytoplasmic membranes from Streptomyces hygroscopicus and its stable protoplast-type L form. J. Bacteriol. 1997, 179, 3430-3436. [PubMed]

62. Nandedkar, A.K.N. Comparative study of the lipid-composition of particular pathogenic and non-pathogenic species of Mycobacterium. J. Natl. Med. Assoc. 1983, 75, 69-74. [PubMed]

63. Sareen, M.; Khuller, G.K. Cell wall and membrane changes associated with ethambutol resistance in Mycobacterium tuberculosis H37Ra. Antimicrob. Agents Chemother. 1990, 34, 1773-1776. [CrossRef] [PubMed]

64. Rottem, S.; Razin, S. Membrane lipids of Mycoplasma hominis. J. Bacteriol. 1973, 113, 565-571. [PubMed]

65. Ward, J.B.; Perkins, H.R. The chemical composition of the membranes of protoplasts and L-forms of Staphylococcus. Biochem. J. 1968, 106, 391-400. [CrossRef] [PubMed]

66. Drucker, D.B.; Wardle, H.M.; Boote, V. Phospholipid profiles of Clostridium difficile. J. Bacteriol. 1996, 178, 5844-5846. [PubMed]

67. Clejan, S.; Krulwich, T.A; Mondrus, K.R.; Seto-Young, D. Membrane lipid composition of obligately and facultatively alkalophilic strains of Bacillus spp. J. Bacteriol. 1986, 168, 334-340. 
68. den Kamp, J.A.; Redai, I.; van Deenen, L.L. Phospholipid composition of Bacillus subtilis. J. Bacteriol. 1969, 99, 298-303. [PubMed]

69. Bishop, D.G.; Rutberg, L.; Samuelsson, B. The chemical composition of the cytoplasmic membrane of Bacillus subtilis. Eur. J. Biochem. 1967, 2, 448-453. [CrossRef] [PubMed]

70. Crandall, A.D.; Montville, T.J. Nisin resistance in Listeria monocytogenes ATCC 700302 is a complex phenotype. Appl. Environ. Microbiol. 1998, 64, 231-237. [PubMed]

71. Errington, J. L-form bacteria, cell walls and the origins of life. Open Biol. 2013, 3, 120143. [CrossRef] [PubMed]

72. Gan, L.; Chen, S.; Jensen, G.J. Molecular organization of Gram-negative peptidoglycan. Proc. Natl. Acad. Sci. USA 2008, 105, 18953-18957. [CrossRef] [PubMed]

73. Kim, S.J.; Chang, J.; Singh, M. Peptidoglycan architecture of Gram-positive bacteria by solid-state NMR. Biochim. Biophys. Acta Biomembr. 2015, 1848, 350-362. [CrossRef] [PubMed]

74. Breukink, E.; de Kruijff, B. Lipid II as a target for antibiotics. Nat. Rev. Drug Discov. 2006, 5, $321-332$. [CrossRef] [PubMed]

75. Beeby, M.; Gumbart, J.C.; Roux, B.; Jensen, G.J. Architecture and assembly of the Gram-positive cell wall. Mol. Microbiol. 2013, 88, 664-672. [CrossRef] [PubMed]

76. Hayhurst, E.J.; Kailas, L.; Hobbs, J.K.; Foster, S.J. Cell wall peptidoglycan architecture in Bacillus subtilis. Proc. Natl. Acad. Sci. USA 2008, 105, 14603-14608. [CrossRef] [PubMed]

77. Percy, M.G.; Grundling, A. Lipoteichoic acid synthesis and function in Gram-positive bacteria. Annu. Rev. Microbiol. 2014, 68, 81-100. [CrossRef] [PubMed]

78. Brown, S.; Santa, M.J., Jr.; Walker, S. Wall teichoic acids of Gram-positive bacteria. Annu. Rev. Microbiol. 2013, 67, 313-336. [CrossRef] [PubMed]

79. Schneewind, O.; Missiakas, D. Lipoteichoic acids, phosphate-containing polymers in the envelope of Gram-positive bacteria. J. Bacteriol. 2014, 196, 1133-1142. [CrossRef] [PubMed]

80. Reichmann, N.T.; Grundling, A. Location, synthesis and function of glycolipids and polyglycerolphosphate lipoteichoic acid in Gram-positive bacteria of the phylum Firmicutes. FEMS Microbiol. Lett. 2011, 319, 97-105. [CrossRef] [PubMed]

81. Naumova, I.B.; Shashkov, A.S.; Tul'skaya, E.M.; Streshinskaya, G.M.; Kozlova, Y.I.; Potekhina, N.V.; Evtushenko, L.I.; Stackebrandt, E. Cell wall teichoic acids: structural diversity, species specificity in the genus Nocardiopsis, and chemotaxonomic perspective. FEMS Microbiol. Rev. 2001, 25, 269-283. [CrossRef] [PubMed]

82. Fischer, W. Physiology of lipoteichoic acids in bacteria. Adv. Microb. Physiol. 1988, 29, 233-302. [PubMed]

83. Gutberlet, T.; Frank, J.; Bradaczek, H.; Fischer, W. Effect of lipoteichoic acid on thermotropic membrane properties. J. Bacteriol. 1997, 179, 2879-2883. [PubMed]

84. Oku, Y.; Kurokawa, K.; Matsuo, M.; Yamada, S.; Lee, B.L.; Sekimizu, K. Pleiotropic roles of polyglycerolphosphate synthase of lipoteichoic acid in growth of Staphylococcus aureus cells. J. Bacteriol. 2009, 191, 141-151. [CrossRef] [PubMed]

85. Huff, E. Lipoteichoic acid, a major amphiphile of Gram-positive bacteria that is not readily extractable. J. Bacteriol. 1982, 149, 399-402. [PubMed]

86. Koch, H.U.; Haas, R.; Fischer, W. The role of lipoteichoic acid biosynthesis in membrane lipid metabolism of growing Staphylococcus aureus. Eur. J. Biochem. 1984, 138, 357-363. [CrossRef] [PubMed]

87. Gutberlet, T.; Markwitz, S.; Labischinski, H.; Bradaczek, H. Monolayer investigations on the bacterial amphiphile lipoteichoic acid and on lipoteichoic acid/dipalmitoyl-phosphatidylglycerol mixtures. Makromol. Chem. Macromol. Symp. 1991, 46, 283-287. [CrossRef]

88. Labischinski, H.; Naumann, D.; Fischer, W. Small and medium-angle X-ray analysis of bacterial lipoteichoic acid phase structure. Eur. J. Biochem. 1991, 202, 1269-1274. [CrossRef] [PubMed]

89. Fischer, W.; Markwitz, S.; Labischinski, H. Small-angle X-ray scattering analysis of pneumococcal lipoteichoic acid phase structure. Eur. J. Biochem. 1997, 244, 913-917. [CrossRef] [PubMed]

90. Courtney, H.S.; Simpson, W.A.; Beachey, E.H. Relationship of critical micelle concentrations of bacterial lipoteichoic acids to biological activities. Infect. Immun. 1986, 51, 414-418. [PubMed]

91. Mitchell, N.J.; Seaton, P.; Pokorny, A. Branched phospholipids render lipid vesicles more susceptible to membrane-active peptides. Biochim. Biophys. Acta Biomembr. 2016, 1858, 988-994. [CrossRef] [PubMed]

92. Rappolt, M.; Hickel, A.; Bringezu, F.; Lohner, K. Mechanism of the lamellar/inverse hexagonal phase transition examined by high resolution X-ray diffraction. Biophys. J. 2003, 84, 3111-3122. [CrossRef] 
93. Seddon, J.M. Structure of the inverted hexagonal (HII) phase, and non-lamellar phase transitions of lipids. Biochim. Biophys. Acta Biomembr. 1990, 1031, 1-69. [CrossRef]

94. Epand, R.M.; Hui, S.W. Effect of electrostatic repulsion on the morphology and thermotropic transitions of anionic phospholipids. FEBS Lett. 1986, 209, 257-260. [CrossRef]

95. Prossnigg, F.; Hickel, A.; Pabst, G.; Lohner, K. Packing behaviour of two predominant anionic phospholipids of bacterial cytoplasmic membranes. Biophys. Chem. 2010, 150, 129-135. [CrossRef] [PubMed]

96. Israelachvili, J.N.; Marcelja, S.; Horn, R.G. Physical principles of membrane organization. Q. Rev. Biophys. 1980, 13, 121-200. [CrossRef] [PubMed]

97. Pink, D.A.; McNeil, S.; Quinn, B.; Zuckermann, M.J. A model of hydrogen bond formation in phosphatidylethanolamine bilayers. Biochim. Biophys. Acta Biomembr. 1998, 1368, 289-305. [CrossRef]

98. Boggs, J.M. Lipid intermolecular hydrogen bonding: Influence on structural organization and membrane-function. Biochim. Biophys. Acta Biomembr. 1987, 906, 353-404. [CrossRef]

99. Lohner, K.; Latal, A.; Degovics, G.; Garidel, P. Packing characteristics of a model system mimicking cytoplasmic bacterial membranes. Chem. Phys. Lipids 2001, 111, 177-192. [CrossRef]

100. Pozo, N.B.; Lohner, K.; Deutsch, G.; Sevcsik, E.; Riske, K.A.; Dimova, R.; Garidel, P.; Pabst, G. Composition dependence of vesicle morphology and mixing properties in a bacterial model membrane system. Biochim. Biophys. Acta Biomembr. 2005, 1716, 40-48. [CrossRef] [PubMed]

101. Haiens, T.H.; Dencher, N.A. Cardiolipin: A proton trap for oxidative phosphorylation. FEBS Lett. 2002, 528, 35-39. [CrossRef]

102. Lewis, R.N.; McElhaney, R.N. The physicochemical properties of cardiolipin bilayers and cardiolipin-containing lipid membranes. Biochim. Biophys. Acta Biomembr. 2009, 1788, 2069-2079. [CrossRef] [PubMed]

103. Rand, R.P.; SenGupta, S. Cardiolipin forms hexagonal structures with divalent cations. Biochim. Biophys. Acta Biomembr. 1972, 255, 484-492. [CrossRef]

104. Mileykovskaya, E.; Dowhan, W. Visualization of phospholipid domains in Escherichia coli by using the cardiolipin-specific fluorescent dye 10-N-nonyl acridine orange. J. Bacteriol. 2000, 182, 1172-1175. [CrossRef] [PubMed]

105. Kawai, F.; Shoda, M.; Harashima, R.; Sadaie, Y.; Hara, H.; Matsumoto, K. Cardiolipin domains in Bacillus subtilis marburg membranes. J. Bacteriol. 2004, 186, 1475-1483. [CrossRef] [PubMed]

106. Mileykovskaya, E.; Dowhan, W. Cardiolipin membrane domains in prokaryotes and eukaryotes. Biochim. Biophys. Acta Biomembr. 2009, 1788, 2084-2091. [CrossRef] [PubMed]

107. Renner, L.D.; Weibel, D.B. Cardiolipin microdomains localize to negatively curved regions of Escherichia coli membranes. Proc. Natl. Acad. Sci. USA 2011, 108, 6264-6269. [CrossRef] [PubMed]

108. Frias, M.; Benesch, M.G.; Lewis, R.N.; McElhaney, R.N. On the miscibility of cardiolipin with 1,2-diacyl phosphoglycerides: Binary mixtures of dimyristoylphosphatidylethanolamine and tetramyristoylcardiolipin. Biochim. Biophys. Acta Biomembr. 2011, 1808, 774-783. [CrossRef] [PubMed]

109. Benesch, M.G.; Lewis, R.N.; McElhaney, R.N. On the miscibility of cardiolipin with 1,2-diacyl phosphoglycerides: Binary mixtures of dimyristoylphosphatidylglycerol and tetramyristoylcardiolipin. Biochim. Biophys. Acta Biomembr. 2015, 1848, 2878-2888. [CrossRef] [PubMed]

110. Barak, I.; Muchova, K.; Wilkinson, A.J.; O’Toole, P.J.; Pavlendova, N. Lipid spirals in Bacillus subtilis and their role in cell division. Mol. Microbiol. 2008, 68, 1315-1327. [CrossRef] [PubMed]

111. Pomorski, T.G.; Nylander, T.; Cardenas, M. Model cell membranes: Discerning lipid and protein contributions in shaping the cell. Adv. Colloid Interface Sci. 2014, 205, 207-220. [CrossRef] [PubMed]

112. Barak, I.; Muchova, K. The role of lipid domains in bacterial cell processes. Int. J. Mol. Sci. 2013, 14, 4050-4065. [CrossRef] [PubMed]

113. White, D.C.; Frerman, F.E. Fatty acid composition of the complex lipids of Staphylococcus aureus during the formation of the membrane-bound electron transport system. J. Bacteriol. 1968, 95, 2198-2209. [PubMed]

114. Kuhn, S.; Slavetinsky, C.J.; Peschel, A. Synthesis and function of phospholipids in Staphylococcus aureus. Int. J. Med. Microbiol. 2015, 305, 196-202. [CrossRef] [PubMed]

115. Mishra, N.N.; Bayer, A.S. Correlation of cell membrane lipid profiles with daptomycin resistance in methicillin-resistant Staphylococcus aureus. Antimicrob. Agents Chemother. 2013, 57, 1082-1085. [CrossRef] [PubMed]

116. Hebeler, B.H.; Chatterjee, A.N.; Young, F.E. Regulation of the bacterial cell wall: Effect of antibiotics on lipid biosynthesis. Antimicrob. Agents Chemother. 1973, 4, 346-353. [CrossRef] [PubMed] 
117. Peschel, A.; Jack, R.W.; Otto, M.; Collins, L.V.; Staubitz, P.; Nicholson, G.; Kalbacher, H.; Nieuwenhuizen, W.F.; Jung, G.; Tarkowski, A.; et al. Staphylococcus aureus resistance to human defensins and evasion of neutrophil killing via the novel virulence factor $m p r F$ is based on modification of membrane lipids with L-lysine. J. Exp. Med. 2001, 193, 1067-1076. [CrossRef] [PubMed]

118. Kristian, S.A.; Durr, M.; Van Strijp, J.A.; Neumeister, B.; Peschel, A. MprF-mediated lysinylation of phospholipids in Staphylococcus aureus leads to protection against oxygen-independent neutrophil killing. Infect. Immun. 2003, 71, 546-549. [CrossRef] [PubMed]

119. Danner, S.; Pabst, G.; Lohner, K.; Hickel, A. Structure and thermotropic behavior of the Staphylococcus aureus lipid lysyl-dipalmitoylphosphatidylglycerol. Biophys. J. 2008, 94, 2150-2159. [CrossRef] [PubMed]

120. Gago, G.; Diacovich, L.; Arabolaza, A.; Tsai, S.C.; Gramajo, H. Fatty acid biosynthesis in actinomycetes. FEMS Microbiol. Rev. 2011, 35, 475-497. [CrossRef] [PubMed]

121. Hwang, F.; Wen, D.C.; Wu, Y.W.; Li, Y.Z.; Dong, Q.H.; Wang, S.M. Studies on the phospholipid-composition of pathogenic cell-membranes of Mycoplasma hyopneumoniae. FEBS Lett. 1986, 195, 323-326. [CrossRef]

122. Rance, M.; Jeffrey, K.R.; Tulloch, A.P.; Butler, K.W.; Smith, I.C.P. Effects of cholesterol on the orientational order of unsaturated lipids in the membranes of Acholeplasma laidlawii: A ${ }^{2} \mathrm{H}-\mathrm{NMR}$ study. Biochim. Biophys. Acta Biomembr. 1982, 688, 191-200. [CrossRef]

123. Stockton, G.W.; Johnson, K.G.; Butler, K.W.; Tulloch, A.P.; Boulanger, Y.; Smith, I.C.P.; Davis, J.H.; Bloom, M. Deuterium NMR Study of lipid organization in Acholeplasma laidlawii membranes. Nature 1977, 269, $267-268$.

124. Mercier, R.; Dominguez-Cuevas, P.; Errington, J. Crucial role for membrane fluidity in proliferation of primitive cells. Cell Rep. 2012, 1, 417-423. [CrossRef] [PubMed]

125. Bozic, B.; Svetina, S. Vesicle self-reproduction: The involvement of membrane hydraulic and solute permeabilities. Eur. Phys. J. E 2007, 24, 79-90. [CrossRef] [PubMed]

126. Peterlin, P.; Arrigler, V.; Kogej, K.; Svetina, S.; Walde, P. Growth and shape transformations of giant phospholipid vesicles upon interaction with an aqueous oleic acid suspension. Chem. Phys. Lipids 2009, 159, 67-76. [CrossRef] [PubMed]

127. Brogden, K.A. Antimicrobial peptides: Pore formers or metabolic inhibitors in bacteria? Nat. Rev. Microbiol. 2005, 3, 238-250. [CrossRef] [PubMed]

128. Yeung, A.T.; Gellatly, S.L.; Hancock, R.E. Multifunctional cationic host defence peptides and their clinical applications. Cell Mol. Life Sci. 2011, 68, 2161-2176. [CrossRef] [PubMed]

129. Otvos, L. Antibacterial peptides and proteins with multiple cellular targets. J. Pept. Sci. 2005, 11, 697-706. [CrossRef] [PubMed]

130. Park, C.B.; Kim, H.S.; Kim, S.C. Mechanism of action of the antimicrobial peptide buforin II: Buforin II kills microorganisms by penetrating the cell membrane and inhibiting cellular functions. Biochem. Biophys. Res. Commun. 1998, 244, 253-257. [CrossRef] [PubMed]

131. Krizsan, A.; Prahl, C.; Goldbach, T.; Knappe, D.; Hoffmann, R. Short proline-rich antimicrobial peptides inhibit either the bacterial $70 S$ ribosome or the assembly of its large $50 S$ subunit. Chembiochem 2015, 16, 2304-2308. [CrossRef] [PubMed]

132. Friedrich, C.L.; Moyles, D.; Beveridge, T.J.; Hancock, R.E.W. Antibacterial action of structurally diverse cationic peptides on Gram-positive bacteria. Antimicrob. Agents Chemother. 2000, 44, 2086-2092. [CrossRef] [PubMed]

133. Demchick, P.; Koch, A.L. The permeability of the wall fabric of Escherichia coli and Bacillus subtilis. J. Bacteriol. 1996, 178, 768-773. [PubMed]

134. Torrent, M.; Navarro, S.; Moussaoui, M.; Nogues, M.V.; Boix, E. Eosinophil cationic protein high-affinity binding to bacteria-wall lipopolysaccharides and peptidoglycans. Biochemistry 2008, 47, 3544-3555. [CrossRef] [PubMed]

135. Melo, M.N.; Dugourd, D.; Castanho, M.A. Omiganan pentahydrochloride in the front line of clinical applications of antimicrobial peptides. Recent Pat. Antiinfect. Drug Discov. 2006, 1, 201-207. [CrossRef] [PubMed]

136. Boix, E.; Nogues, M.V. Mammalian antimicrobial proteins and peptides: Overview on the RNase A superfamily members involved in innate host defence. Mol. Biosyst. 2007, 3, 317-335. [CrossRef] [PubMed]

137. Torrent, M.; Cuyas, E.; Carreras, E.; Navarro, S.; Lopez, O.; De La Maza, A.; Nogués, M.V.; Reshetnyak, Y.K.; Boix, E. Topography studies on the membrane interaction mechanism of the eosinophil cationic protein. Biochemistry 2007, 46, 720-733. [CrossRef] [PubMed] 
138. Carreras, E.; Boix, E.; Rosenberg, H.F.; Cuchillo, C.M.; Nogues, M.V. Both aromatic and cationic residues contribute to the membrane-lytic and bactericidal activity of eosinophil cationic protein. Biochemistry 2003, 42, 6636-6644. [CrossRef] [PubMed]

139. Marchand, C.; Krajewski, K.; Lee, H.F.; Antony, S.; Johnson, A.A.; Amin, R.; Roller, P.; Kvaratskhelia, M.; Pommier, Y. Covalent binding of the natural antimicrobial peptide indolicidin to DNA abasic sites. Nucleic Acids Res. 2006, 34, 5157-5165. [CrossRef] [PubMed]

140. Van Bambeke, F.; Mingeot-Leclercq, M.P.; Struelens, M.J.; Tulkens, P.M. The bacterial envelope as a target for novel anti-MRSA antibiotics. Trends Pharmacol. Sci. 2008, 29, 124-134. [CrossRef] [PubMed]

141. Allen, N.E. From vancomycin to oritavancin: The discovery and development of a novel lipoglycopeptide antibiotic. Antiinfect Agents Med. Chem. 2010, 9, 23-47. [CrossRef]

142. Bionda, N.; Pitteloud, J.P.; Cudic, P. Cyclic lipodepsipeptides: A new class of antibacterial agents in the battle against resistant bacteria. Future Med. Chem. 2013, 5, 1311-1330. [CrossRef] [PubMed]

143. Walker, S.; Chen, L.; Hu, Y.; Rew, Y.; Shin, D.; Boger, D.L. Chemistry and biology of ramoplanin: A lipoglycodepsipeptide with potent antibiotic activity. Chem. Rev. 2005, 105, 449-476. [CrossRef] [PubMed]

144. Nam, J.; Shin, D.; Rew, Y.; Boger, D.L. Alanine scan of [L-Dap ${ }^{2}$ ]ramoplanin A2 aglycon: Assessment of the importance of each residue. J. Am. Chem. Soc. 2007, 129, 8747-8755. [CrossRef] [PubMed]

145. Somner, E.A.; Reynolds, P.E. Inhibition of peptidoglycan biosynthesis by ramoplanin. Antimicrob. Agents Chemother. 1990, 34, 413-419. [CrossRef] [PubMed]

146. Cudic, P.; Kranz, J.K.; Behenna, D.C.; Kruger, R.G.; Tadesse, H.; Wand, A.J.; Veklich, Y.I.; Weisel, J.W.; McCafferty, D.G. Complexation of peptidoglycan intermediates by the lipoglycodepsipeptide antibiotic ramoplanin: minimal structural requirements for intermolecular complexation and fibril formation. Proc. Natl. Acad. Sci. USA 2002, 99, 7384-7389. [CrossRef] [PubMed]

147. Fang, X.; Tiyanont, K.; Zhang, Y.; Wanner, J.; Boger, D.; Walker, S. The mechanism of action of ramoplanin and enduracidin. Mol. Biosyst. 2006, 2, 69-76. [CrossRef] [PubMed]

148. Cheng, M.; Huang, J.X.; Ramu, S.; Butler, M.S.; Cooper, M.A. Ramoplanin at bactericidal concentrations induces bacterial membrane depolarization in Staphylococcus aureus. Antimicrob. Agents Chemother. 2014, 58, 6819-6827. [CrossRef] [PubMed]

149. Oppedijk, S.F.; Martin, N.I.; Breukink, E. Hit'em where it hurts: The growing and structurally diverse family of peptides that target lipid-II. Biochim. Biophys. Acta Biomembr. 2016, 1858, 947-957. [CrossRef] [PubMed]

150. Wiedemann, I.; Breukink, E.; van Kraaij, C.; Kuipers, O.P.; Bierbaum, G.; de Kruijff, B.; Sahl, H.G. Specific binding of nisin to the peptidoglycan precursor lipid II combines pore formation and inhibition of cell wall biosynthesis for potent antibiotic activity. J. Biol. Chem. 2001, 276, 1772-1779. [CrossRef] [PubMed]

151. Hasper, H.E.; Kramer, N.E.; Smith, J.L.; Hillman, J.D.; Zachariah, C.; Kuipers, O.P.; De Kruijff, B.; Breukink, E. An alternative bactericidal mechanism of action for lantibiotic peptides that target lipid II. Science 2006, 313, 1636-1637.

152. Hsu, S.T.; Breukink, E.; Tischenko, E.; Lutters, M.A.; de Kruijff, B.; Kaptein, R.; Bonvin, A.M.; van Nuland, N.A. The nisin-lipid II complex reveals a pyrophosphate cage that provides a blueprint for novel antibiotics. Nat. Struct. Mol. Biol. 2004, 11, 963-967. [CrossRef] [PubMed]

153. Breukink, E.; van Heusden, H.E.; Vollmerhaus, P.J.; Swiezewska, E.; Brunner, L.; Walker, S.; Heck, A.J.; de Kruijff, B. Lipid II is an intrinsic component of the pore induced by nisin in bacterial membranes. J. Biol. Chem. 2003, 278, 19898-19903. [CrossRef] [PubMed]

154. Brotz, H.; Josten, M.; Wiedemann, I.; Schneider, U.; Gotz, F.; Bierbaum, G.; Sahl, H.G. Role of lipid-bound peptidoglycan precursors in the formation of pores by nisin, epidermin and other lantibiotics. Mol. Microbiol. 1998, 30, 317-327. [CrossRef] [PubMed]

155. de Kruijff, B.; van Dam, V.; Breukink, E. Lipid II: A central component in bacterial cell wall synthesis and a target for antibiotics. Prostaglandins Leukot. Essent. Fatty Acids 2008, 79, 117-121. [CrossRef] [PubMed]

156. Martin, N.I.; Breukink, E. Expanding role of lipid II as a target for lantibiotics. Future Microbiol. 2007, 2, 513-525. [CrossRef] [PubMed]

157. Brotz, H.; Bierbaum, G.; Leopold, K.; Reynolds, P.E.; Sahl, H.G. The lantibiotic mersacidin inhibits peptidoglycan synthesis by targeting lipid II. Antimicrob. Agents Chemother. 1998, 42, 154-160. [PubMed]

158. Schmitt, P.; Wilmes, M.; Pugniere, M.; Aumelas, A.; Bachere, E.; Sahl, H.G.; Schneider, T.; Destoumieux-Garzón, D. Insight into invertebrate defensin mechanism of action: Oyster defensins inhibit peptidoglycan biosynthesis by binding to lipid II. J. Biol. Chem. 2010, 285, 29208-29216. [CrossRef] [PubMed] 
159. Mygind, P.H.; Fischer, R.L.; Schnorr, K.M.; Hansen, M.T.; Sonksen, C.P.; Ludvigsen, S.; Raventós, D.; Buskov, S.; Christensen, B.; De Maria, L.; et al. Plectasin is a peptide antibiotic with therapeutic potential from a saprophytic fungus. Nature 2005, 437, 975-980. [CrossRef] [PubMed]

160. Schmitt, P.; Gueguen, Y.; Desmarais, E.; Bachere, E.; de Lorgeril, J. Molecular diversity of antimicrobial effectors in the oyster Crassostrea gigas. BMC Evol. Biol. 2010, 10, 23. [CrossRef] [PubMed]

161. Schmitt, P.; Rosa, R.D.; Destoumieux-Garzon, D. An intimate link between antimicrobial peptide sequence diversity and binding to essential components of bacterial membranes. Biochim. Biophys. Acta Biomembr. 2016, 1858, 958-970. [CrossRef] [PubMed]

162. Zhanel, G.G.; Schweizer, F.; Karlowsky, J.A. Oritavancin: Mechanism of action. Clin. Infect. Dis. 2012, 54, S214-S219. [CrossRef] [PubMed]

163. Belley, A.; McKay, G.A.; Arhin, F.F.; Sarmiento, I.; Beaulieu, S.; Fadhil, I.; Parr, T.R.; Moeck, G. Oritavancin disrupts membrane integrity of Staphylococcus aureus and vancomycin-resistant enterococci to effect rapid bacterial killing. Antimicrob. Agents Chemother. 2010, 54, 5369-5371. [CrossRef] [PubMed]

164. Belley, A.; Neesham-Grenon, E.; McKay, G.; Arhin, F.F.; Harris, R.; Beveridge, T.; Parr, T.R.; Moeck, G. Oritavancin kills stationary-phase and biofilm Staphylococcus aureus cells in vitro. Antimicrob. Agents Chemother. 2009, 53, 918-925. [CrossRef] [PubMed]

165. Domenech, O.; Dufrene, Y.F.; Van Bambeke, F.; Tukens, P.M.; Mingeot-Leclercq, M.P. Interactions of oritavancin, a new semi-synthetic lipoglycopeptide, with lipids extracted from Staphylococcus aureus. Biochim. Biophys. Acta Biomembr. 2010, 1798, 1876-1885. [CrossRef] [PubMed]

166. Domenech, O.; Francius, G.; Tulkens, P.M.; Van Bambeke, F.; Dufrene, Y.; Mingeot-Leclercq, M.P. Interactions of oritavancin, a new lipoglycopeptide derived from vancomycin, with phospholipid bilayers: Effect on membrane permeability and nanoscale lipid membrane organization. Biochim. Biophys. Acta Biomembr. 2009, 1788, 1832-1840. [CrossRef] [PubMed]

167. Arthur, M.; Depardieu, F.; Reynolds, P.; Courvalin, P. Moderate-level resistance to glycopeptide LY333328 mediated by genes of the vanA and vanB clusters in enterococci. Antimicrob. Agents Chemother. 1999, 43, 1875-1880. [PubMed]

168. Stone, K.J.; Strominger, J.L. Mechanism of action of bacitracin: Complexation with metal ion and $\mathrm{C}_{55}$-isoprenyl pyrophosphate. Proc. Natl. Acad. Sci. USA 1971, 68, 3223-3227. [CrossRef] [PubMed]

169. Schneider, T.; Gries, K.; Josten, M.; Wiedemann, I.; Pelzer, S.; Labischinski, H.; Sahl, H.G. The lipopeptide antibiotic friulimicin B inhibits cell wall biosynthesis through complex formation with bactoprenol phosphate. Antimicrob. Agents Chemother. 2009, 53, 1610-1618. [CrossRef] [PubMed]

170. Straus, S.K.; Hancock, R.E.W. Mode of action of the new antibiotic for Gram-positive pathogens daptomycin: Comparison with cationic antimicrobial peptides and lipopeptides. Biochim. Biophys. Acta Biomembr. 2006, 1758, 1215-1223. [CrossRef] [PubMed]

171. Guan, R.; Mariuzza, R.A. Peptidoglycan recognition proteins of the innate immune system. Trends Microbiol. 2007, 15, 127-134. [CrossRef] [PubMed]

172. Lehotzky, R.E.; Partch, C.L.; Mukherjee, S.; Cash, H.L.; Goldman, W.E.; Gardner, K.H.; Hooper, L.V. Molecular basis for peptidoglycan recognition by a bactericidal lectin. Proc. Natl. Acad. Sci. USA 2010, 107, 7722-7727. [CrossRef] [PubMed]

173. Svajger, U.; Anderluh, M.; Jeras, M.; Obermajer, N. C-type lectin DC-SIGN: An adhesion, signalling and antigen-uptake molecule that guides dendritic cells in immunity. Cell. Signal. 2010, 22, 1397-1405. [CrossRef] [PubMed]

174. Mukherjee, S.; Zheng, H.; Derebe, M.G.; Callenberg, K.M.; Partch, C.L.; Rollins, D.; Propheter, D.C.; Rizo, J.; Grabe, M.; Jiang, Q.X. Antibacterial membrane attack by a pore-forming intestinal C-type lectin. Nature 2014, 505, 103-107. [CrossRef] [PubMed]

175. Merle, N.S.; Church, S.E.; Fremeaux-Bacchi, V.; Roumenina, L.T. Complement system part I-molecular mechanisms of activation and regulation. Front. Immunol. 2015, 6, 262. [CrossRef] [PubMed]

176. Merle, N.S.; Noe, R.; Halbwachs-Mecarelli, L.; Fremeaux-Bacchi, V.; Roumenina, L.T. Complement system part II: Role in immunity. Front. Immunol. 2015, 6, 257. [CrossRef] [PubMed]

177. Sevcsik, E.; Pabst, G.; Richter, W.; Danner, S.; Amenitsch, H.; Lohner, K. Interaction of LL-37 with model membrane systems of different complexity: Influence of the lipid matrix. Biophys. J. 2008, 94, 4688-4699. [CrossRef] [PubMed] 
178. Scott, M.G.; Gold, M.R.; Hancock, R.E. Interaction of cationic peptides with lipoteichoic acid and Gram-positive bacteria. Infect. Immun. 1999, 67, 6445-6453. [PubMed]

179. Bucki, R.; Janmey, P.A. Interaction of the gelsolin-derived antibacterial PBP 10 peptide with lipid bilayers and cell membranes. Antimicrob. Agents Chemother. 2006, 50, 2932-2940. [CrossRef] [PubMed]

180. Vadyvaloo, V.; Arous, S.; Gravesen, A.; Hechard, Y.; Chauhan-Haubrock, R.; Hastings, J.W.; Rautenbach, M. Cell-surface alterations in class IIa bacteriocin-resistant Listeria monocytogenes strains. Microbiology 2004, 150, 3025-3033. [CrossRef] [PubMed]

181. Li, Z.; Zhang, S.; Zhang, J.; Liu, M.; Liu, Z. Vitellogenin is a cidal factor capable of killing bacteria via interaction with lipopolysaccharide and lipoteichoic acid. Mol. Immunol. 2009, 46, 3232-3239. [CrossRef] [PubMed]

182. Malanovic, N.; Leber, R.; Schmuck, M.; Kriechbaum, M.; Cordfunke, R.A.; Drijfhout, J.W.; de Breij, A.; Nibbering, P.H.; Kolb, D.; Lohner, K. Phospholipid-driven differences determine the action of the synthetic antimicrobial peptide OP-145 on Gram-positive bacterial and mammalian membrane model systems. Biochim. Biophys. Acta Biomembr. 2015, 1848, 2437-2447. [CrossRef] [PubMed]

183. Liu, W.H.; Kao, P.H.; Lin, S.R.; Chang, L.S. Membrane-damaging activity with A chain and B chain of $\beta$-bungarotoxin. Toxicon 2009, 53, 262-268. [CrossRef] [PubMed]

184. Wen, Y.L.; Wu, B.J.; Kao, P.H.; Fu, Y.S.; Chang, L.S. Antibacterial and membrane-damaging activities of $\beta$-bungarotoxin B chain. J. Pept. Sci. 2013, 19, 1-8. [PubMed]

185. Koprivnjak, T.; Weidenmaier, C.; Peschel, A.; Weiss, J.P. Wall teichoic acid deficiency in Staphylococcus aureus confers selective resistance to mammalian group IIA phospholipase $\mathrm{A}_{2}$ and human $\beta$-defensin 3. Infect. Immun. 2008, 76, 2169-2176. [CrossRef] [PubMed]

186. Fischer, W.; Rosel, P. The alanine ester substitution of lipoteichoic acid (LTA) in Staphylococcus aureus. FEBS Lett. 1980, 119, 224-226. [CrossRef]

187. Collins, L.V.; Kristian, S.A.; Weidenmaier, C.; Faigle, M.; van Kessel, K.P.; Van Strijp, J.A.; Gotz, F.; Neumeister, B.; Peschel, A. Staphylococcus aureus strains lacking D-alanine modifications of teichoic acids are highly susceptible to human neutrophil killing and are virulence attenuated in mice. J. Infect. Dis. 2002, 186, 214-219. [CrossRef] [PubMed]

188. Peschel, A.; Vuong, C.; Otto, M.; Gotz, F. The D-alanine residues of Staphylococcus aureus teichoic acids alter the susceptibility to vancomycin and the activity of autolytic enzymes. Antimicrob. Agents Chemother. 2000, 44, 2845-2847. [CrossRef] [PubMed]

189. Peschel, A.; Otto, M.; Jack, R.W.; Kalbacher, H.; Jung, G.; Gotz, F. Inactivation of the dlt operon in Staphylococcus aureus confers sensitivity to defensins, protegrins, and other antimicrobial peptides. J. Biol. Chem. 1999, 274, 8405-8410. [CrossRef] [PubMed]

190. Wang, H.; Gill, C.J.; Lee, S.H.; Mann, P.; Zuck, P.; Meredith, T.C.; Murgolo, N.; She, X.; Kales, S.; Liang, L.; et al. Discovery of wall teichoic acid inhibitors as potential anti-MRSA $\beta$-lactam combination agents. Chem. Biol. 2013, 20, 272-284. [CrossRef] [PubMed]

191. Saar-Dover, R.; Bitler, A.; Nezer, R.; Shmuel-Galia, L.; Firon, A.; Shimoni, E.; Trieu-Cuot, P.; Shai, Y. D-alanylation of lipoteichoic acids confers resistance to cationic peptides in group B Streptococcus by increasing the cell wall density. PLoS Pathog. 2012, 8, e1002891. [CrossRef]

192. Zhang, S.; Wang, S.; Li, H.; Li, L. Vitellogenin, a multivalent sensor and an antimicrobial effector. Int. J. Biochem. Cell Biol. 2011, 43, 303-305. [CrossRef] [PubMed]

193. Wu, B.; Liu, Z.; Zhou, L.; Ji, G.; Yang, A. Molecular cloning, expression, purification and characterization of vitellogenin in scallop Patinopecten yessoensis with special emphasis on its antibacterial activity. Dev. Comp. Immunol. 2015, 49, 249-258. [CrossRef] [PubMed]

194. Hoernke, M.; Schwieger, C.; Kerth, A.; Blume, A. Binding of cationic pentapeptides with modified side chain lengths to negatively charged lipid membranes: Complex interplay of electrostatic and hydrophobic interactions. Biochim. Biophys. Acta Biomembr. 2012, 1818, 1663-1672. [CrossRef] [PubMed]

195. Lohner, K. DSC Studies on the modulation of membrane lipid polymorphism and domain organization by antimicrobial peptides. In Biocalorimetry: Foundations and Contemporary Approaches; Bastos, M., Ed.; CRC Press: Boca Raton, FL, USA, 2016; pp. 169-190.

196. Shai, Y. Mode of action of membrane active antimicrobial peptides. Biopolymers 2002, 66, 236-248. [CrossRef] [PubMed] 
197. Matsuzaki, K.; Murase, O.; Fujii, N.; Miyajima, K. An antimicrobal peptide, magainin 2, induced rapid flip-flop of phospholipids coupled with pore formation and peptide translocation. Biochemistry 1996, 35, 11361-11368. [CrossRef] [PubMed]

198. Bartucci, R.; Guzzi, R.; Sportelli, L.; Marsh, D. Intramembrane water associated with TOAC spin-labeled alamethicin: Electron spin-echo envelope modulation by $\mathrm{D}_{2} \mathrm{O}$. Biophys. J. 2009, 96, 997-1007. [CrossRef] [PubMed]

199. Qian, S.; Wang, W.C.; Yang, L.; Huang, H.W. Structure of the alamethicin pore reconstructed by X-ray diffraction analysis. Biophys. J. 2008, 94, 3512-3522. [CrossRef] [PubMed]

200. Pieta, P.; Mirza, J.; Lipkowski, J. Direct visualization of the alamethicin pore formed in a planar phospholipid matrix. Proc. Natl. Acad. Sci. USA 2012, 109, 21223-21227. [CrossRef] [PubMed]

201. He, K.; Ludtke, S.J.; Heller, W.T.; Huang, H.W. Mechanism of alamethicin insertion into lipid bilayers. Biophys. J. 1996, 71, 2669-2679. [CrossRef]

202. Yang, L.; Harroun, T.A.; Weiss, T.M.; Ding, L.; Huang, H.W. Barrel-stave model or toroidal model? A case study on melittin pores. Biophys. J. 2001, 81, 1475-1485. [PubMed]

203. Ludtke, S.J.; He, K.; Heller, W.T.; Harroun, T.A.; Yang, L.; Huang, H.W. Membrane pores induced by magainin. Biochemistry 1996, 35, 13723-13728. [CrossRef] [PubMed]

204. Bechinger, B.; Lohner, K. Detergent-like actions of linear amphipathic cationic antimicrobial peptides. Biochim. Biophys. Acta Biomembr. 2006, 1758, 1529-1539. [CrossRef] [PubMed]

205. Wimley, W.C. Describing the mechanism of antimicrobial peptide action with the interfacial activity model. ACS Chem. Biol. 2010, 5, 905-917. [CrossRef] [PubMed]

206. Kandaswamy, K.; Liew, T.H.; Wang, C.Y.; Huston-Warren, E.; Meyer-Hoffert, U.; Hultenby, K.; Schroder, J.M.; Caparon, M.G.; Normark, S.; Henriques-Normark, B.; et al. Focal targeting by human $\beta$-defensin 2 disrupts localized virulence factor assembly sites in Enterococcus faecalis. Proc. Natl. Acad. Sci. USA 2013, 110, 20230-20235. [CrossRef] [PubMed]

207. Vega, L.A.; Caparon, M.G. Cationic antimicrobial peptides disrupt the Streptococcus pyogenes ExPortal. Mol. Microbiol. 2012, 85, 1119-1132. [CrossRef] [PubMed]

208. Rangarajan, N.; Bakshi, S.; Weisshaar, J.C. Localized permeabilization of E. coli membranes by the antimicrobial peptide Cecropin A. Biochemistry 2013, 52, 6584-6594. [PubMed]

209. Zweytick, D.; Japelj, B.; Mileykovskaya, E.; Zorko, M.; Dowhan, W.; Blondelle, S.E.; Riedl, S.; Jerala, R.; Lohner, K. N-acylated peptides derived from human lactoferricin perturb organization of cardiolipin and phosphatidylethanolamine in cell membranes and induce Defects in Escherichia coli cell division. PLoS ONE 2014, 9, e90228. [CrossRef] [PubMed]

210. Finger, S.; Kerth, A.; Dathe, M.; Blume, A. The efficacy of trivalent cyclic hexapeptides to induce lipid clustering in PG/PE membranes correlates with their antimicrobial activity. Biochim. Biophys. Acta Biomembr. 2015, 1848, 2998-3006. [CrossRef] [PubMed]

211. Scheinpflug, K.; Krylova, O.; Nikolenko, H.; Thurm, C.; Dathe, M. Evidence for a novel mechanism of antimicrobial action of a cyclic R-, W-rich hexapeptide. PLOS ONE 2015, 10, e0125056. [CrossRef] [PubMed]

212. Dowhan, W. Molecular basis for membrane phospholipid diversity: Why are there so many lipids? Annu. Rev. Biochem. 1997, 66, 199-232. [CrossRef] [PubMed]

213. Matsumoto, K.; Kusaka, J.; Nishibori, A.; Hara, H. Lipid domains in bacterial membranes. Mol. Microbiol. 2006, 61, 1110-1117. [CrossRef] [PubMed]

214. Renner, L.D.; Weibel, D.B. MinD and MinE interact with anionic phospholipids and regulate division plane formation in Escherichia coli. J. Biol. Chem. 2012, 287, 38835-38844. [CrossRef] [PubMed]

215. Wenzel, M.; Chiriac, A.I.; Otto, A.; Zweytick, D.; May, C.; Schumacher, C.; Gust, R.; Albada, H.B.; Penkova, M.; Kramer, U.; et al. Small cationic antimicrobial peptides delocalize peripheral membrane proteins. Proc. Natl. Acad. Sci. USA 2014, 111, E1409-E1418. [CrossRef] [PubMed]

216. Wenzel, M.; Schriek, P.; Prochnow, P.; Albada, H.B.; Metzler-Nolte, N.; Bandow, J.E. Influence of lipidation on the mode of action of a small RW-rich antimicrobial peptide. Biochim. Biophys. Acta Biomembr. 2016, 1858, 1004-1011. [CrossRef] [PubMed]

217. Epand, R.M.; Epand, R.F. Lipid domains in bacterial membranes and the action of antimicrobial agents. Biochim. Biophys. Acta Biomembr. 2009, 1788, 289-294. [CrossRef] [PubMed] 
218. Epand, R.F.; Wang, G.; Berno, B.; Epand, R.M. Lipid segregation explains selective toxicity of a series of fragments derived from the human cathelicidin LL-37. Antimicrob. Agents Chemother. 2009, 53, 3705-3714. [CrossRef] [PubMed]

219. Lohner, K.; Prenner, E.J. Differential scanning calorimetry and X-ray diffraction studies of the specificity of the interaction of antimicrobial peptides with membrane-mimetic systems. Biochim. Biophys. Acta Biomembr. 1999, 1462, 141-156. [CrossRef]

220. Epand, R.M.; Epand, R.F.; Arnusch, C.J.; Papahadjopoulos-Sternberg, B.; Wang, G.; Shai, Y. Lipid clustering by three homologous arginine-rich antimicrobial peptides is insensitive to amino acid arrangement and induced secondary structure. Biochim. Biophys. Acta Biomembr. 2010, 1798, 1272-1280. [CrossRef] [PubMed]

221. Epand, R.M.; Epand, R.F. Bacterial membrane lipids in the action of antimicrobial agents. J. Pept. Sci. 2011, 17, 298-305. [CrossRef] [PubMed]

222. Epand, R.F.; Schmitt, M.A.; Gellman, S.H.; Epand, R.M. Role of membrane lipids in the mechanism of bacterial species selective toxicity by two $\alpha / \beta$-antimicrobial peptides. Biochim. Biophys. Acta Biomembr. 2006, 1758, 1343-1350. [CrossRef] [PubMed]

223. Epand, R.F.; Mowery, B.P.; Lee, S.E.; Stahl, S.S.; Lehrer, R.I.; Gellman, S.H.; Epand, R.M. Dual mechanism of bacterial lethality for a cationic sequence-random copolymer that mimics host-defense antimicrobial peptides. J. Mol. Biol. 2008, 379, 38-50. [CrossRef] [PubMed]

224. Radzishevsky, I.S.; Kovachi, T.; Porat, Y.; Ziserman, L.; Zaknoon, F.; Danino, D.; Mor, A. Structure-activity relationships of antibacterial acyl-lysine oligomers. Chem. Biol. 2008, 15, 354-362. [CrossRef] [PubMed]

225. Zaknoon, F.; Sarig, H.; Rotem, S.; Livne, L.; Ivankin, A.; Gidalevitz, D.; Mor, A. Antibacterial properties and mode of action of a short acyl-lysyl oligomer. Antimicrob. Agents Chemother. 2009, 53, 3422-3429. [CrossRef] [PubMed]

226. Epand, R.F.; Maloy, W.L.; Ramamoorthy, A.; Epand, R.M. Probing the "charge cluster mechanism" in amphipathic helical cationic antimicrobial peptides. Biochemistry 2010, 49, 4076-4084. [CrossRef] [PubMed]

227. Hobbs, J.K.; Miller, K.; O’Neill, A.J.; Chopra, I. Consequences of daptomycin-mediated membrane damage in Staphylococcus aureus. J. Antimicrob. Chemother. 2008, 62, 1003-1008. [CrossRef] [PubMed]

228. Silverman, J.A.; Perlmutter, N.G.; Shapiro, H.M. Correlation of daptomycin bactericidal activity and membrane depolarization in Staphylococcus aureus. Antimicrob. Agents Chemother. 2003, 47, 2538-2544. [CrossRef] [PubMed]

229. Zhang, T.; Muraih, J.K.; MacCormick, B.; Silverman, J.; Palmer, M. Daptomycin forms cation- and size-selective pores in model membranes. Biochim. Biophys. Acta Biomembr. 2014, 1838, 2425-2430. [CrossRef] [PubMed]

230. Haney, E.F.; Nathoo, S.; Vogel, H.J.; Prenner, E.J. Induction of non-lamellar lipid phases by antimicrobial peptides: A potential link to mode of action. Chem. Phys. Lipids 2010, 163, 82-93. [CrossRef] [PubMed]

231. Zhang, T.; Muraih, J.K.; Tishbi, N.; Herskowitz, J.; Victor, R.L.; Silverman, J.; Uwumarenogie, S.; Taylor, S.D.; Palmer, M.; Mintzer, E. Cardiolipin prevents membrane translocation and permeabilization by daptomycin. J. Biol. Chem. 2014, 289, 11584-11591. [CrossRef] [PubMed]

232. Huang, H.W. Molecular mechanism of antimicrobial peptides: The origin of cooperativity. Biochim. Biophys. Acta Biomembr. 2006, 1758, 1292-1302. [CrossRef] [PubMed]

233. Koller, D.; Lohner, K. The role of spontaneous lipid curvature in the interaction of interfacially active peptides with membranes. Biochim. Biophys. Acta Biomembr. 2014, 1838, 2250-2259. [CrossRef] [PubMed]

234. Sevcsik, E.; Pabst, G.; Jilek, A.; Lohner, K. How lipids influence the mode of action of membrane-active peptides. Biochim. Biophys. Acta Biomembr. 2007, 1768, 2586-2595. [CrossRef] [PubMed]

235. Staudegger, E.; Prenner, E.J.; Kriechbaum, M.; Degovics, G.; Lewis, R.N.; McElhaney, R.N.; Lohner, K. X-ray studies on the interaction of the antimicrobial peptide gramicidin $S$ with microbial lipid extracts: Evidence for cubic phase formation. Biochim. Biophys. Acta Biomembr. 2000, 1468, 213-230. [CrossRef]

236. Ludtke, S.; He, K.; Huang, H. Membrane thinning caused by magainin 2. Biochemistry 1995, 34, 16764-16769. [CrossRef] [PubMed]

237. Chen, Y.F.; Sun, T.L.; Sun, Y.; Huang, H.W. Interaction of daptomycin with lipid bilayers: A lipid extracting effect. Biochemistry 2014, 53, 5384-5392. [CrossRef] [PubMed]

238. Pogliano, J.; Pogliano, N.; Silverman, J.A. Daptomycin-mediated reorganization of membrane architecture causes mislocalization of essential cell division proteins. J. Bacteriol. 2012, 194, 4494-4504. [CrossRef] [PubMed] 
239. Anderson, T.M.; Clay, M.C.; Cioffi, A.G.; Diaz, K.A.; Hisao, G.S.; Tuttle, M.D.; Nieuwkoop, A.J.; Comellas, G.; Maryum, N.; Wang, S.; et al. Amphotericin forms an extramembranous and fungicidal sterol sponge. Nat. Chem. Biol. 2014, 10, 400-406. [CrossRef] [PubMed]

240. Lohner, K. Antimicrobial mechanisms: A sponge against fungal infections. Nat. Chem. Biol. 2014, 10, 411-412. [CrossRef] [PubMed]

241. Yang, S.J.; Xiong, Y.Q.; Dunman, P.M.; Schrenzel, J.; Francois, P.; Peschel, A.; Bayer, A.S. Regulation of $m p r F$ in daptomycin-nonsusceptible Staphylococcus aureus strains. Antimicrob. Agents Chemother. 2009, 53, 2636-2637. [CrossRef] [PubMed]

242. Arias, C.A.; Panesso, D.; McGrath, D.M.; Qin, X.; Mojica, M.F.; Miller, C.; Diaz, L.; Tran, T.T.; Rincon, S.; Barbu, E.M.; et al. Genetic basis for in vivo daptomycin resistance in enterococci. N. Engl. J. Med. 2011, 365, 892-900. [CrossRef] [PubMed]

243. Hachmann, A.; Sevim, E.; Gaballa, A.; Popham, D.L.; Antelmann, H.; Helmann, J.D. Reduction in membrane phosphatidylglycerol content leads to daptomycin resistance in Bacillus subtilis. Antimicrob. Agents Chemother. 2011, 55, 4326-4337. [CrossRef] [PubMed]

244. Lenarcic, R.; Halbedel, S.; Visser, L.; Shaw, M.; Wu, L.J.; Errington, J.; Marenduzzo, D.; Hamoen, L.W. Localisation of DivIVA by targeting to negatively curved membranes. EMBO J. 2009, 28, 2272-2282. [CrossRef] [PubMed]

245. Tran, T.T.; Panesso, D.; Mishra, N.N.; Mileykovskaya, E.; Guan, Z.; Munita, J.M.; Reyes, J.; Diaz, L.; Weinstock, G.M.; Murray, B.E.; et al. Daptomycin-resistant Enterococcus faecalis diverts the antibiotic molecule from the division septum and remodels cell membrane phospholipids. MBio 2013, 4, e00281-e002813. [CrossRef] [PubMed]

(C) 2016 by the authors; licensee MDPI, Basel, Switzerland. This article is an open access article distributed under the terms and conditions of the Creative Commons Attribution (CC-BY) license (http://creativecommons.org/licenses/by/4.0/). 